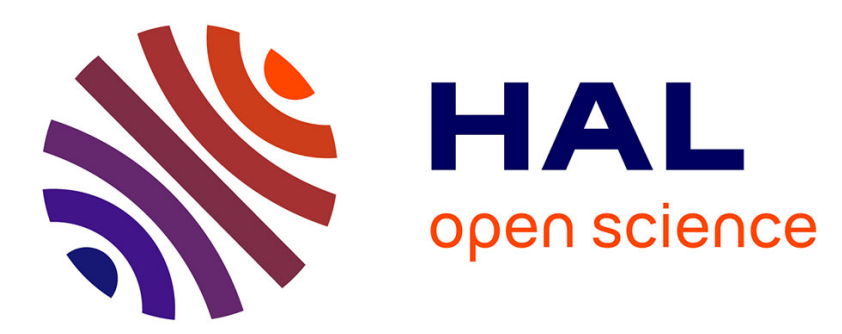

\title{
Environmental changes and cultural dynamics along the northern slope of the Pyrenees during the Younger Dryas
}

\author{
Michel Barbaza
}

\section{- To cite this version:}

Michel Barbaza. Environmental changes and cultural dynamics along the northern slope of the Pyrenees during the Younger Dryas. Quaternary International, 2011, 242 (2), pp.313-327. 10.1016/j.quaint.2011.03.012 . hal-01995332

\section{HAL Id: hal-01995332 \\ https://hal.science/hal-01995332}

Submitted on 15 Feb 2019

HAL is a multi-disciplinary open access archive for the deposit and dissemination of scientific research documents, whether they are published or not. The documents may come from teaching and research institutions in France or abroad, or from public or private research centers.
L'archive ouverte pluridisciplinaire HAL, est destinée au dépôt et à la diffusion de documents scientifiques de niveau recherche, publiés ou non, émanant des établissements d'enseignement et de recherche français ou étrangers, des laboratoires publics ou privés. 


\title{
Environmental changes and cultural dynamics along the northern slope of the Pyrenees during the Younger Dryas
}

\author{
Michel Barbaza \\ TRACES, UMR 5608, Université de Toulouse, CNRS, Maison de la Recherche, 5 allée Antonio-Machado, 31058 Toulouse, France
}

\section{A R T I C L E I N F O}

\section{Article history:}

Available online $\mathrm{xxx}$

\begin{abstract}
A B S T R A C T
Paradoxically, the region of the northern Pyrenean piedmont, a pioneering location for research on the very end of the last glacial period, suffers from a scarcity of recent and well-documented studies. A few recently or soon to be published sites nevertheless enable a presentation of the first elements of analysis and reflection in a global consideration of the societies of this period, which sees the concomitance of the Younger Dryas cold phase and the classic Pyrenean Azilian. A detailed examination of these two phenomena shows that their relationships are more complex than those of simple ecological determinism.
\end{abstract}

(c) 2011 Elsevier Ltd and INQUA. All rights reserved.

\section{An evolutionary dynamic between nature and culture}

\subsection{Preamble}

As all others of this kind, this presentation adheres to a preexisting theoretical framework which, despite a real concern for objectivity, entails the risk of being influenced by a certain number of prejudices unfavourable to an exact reconstruction of the past. The compilation of this summary nevertheless has the double advantage of gathering disparate data, often little-known or unpublished, and of ordering these into a draft model, to be confirmed or refuted. The general contribution of this work will emerge when the data originating from the northern slope of the Pyrenees are integrated, first within the long period of the late Final Pleistocene and the start of the Holocene, and second within the relatively broad regional context of the northern Iberian Peninsula and southwestern France (Fig. 1).

Combinations of environmental data and traces of human activity inevitably lead to the idea that there was a dependency relationship underlying the creation of these two types of evidence. Without denying that a certain level of analysis can make this type of link apparent, it seems that the more or less conscious integration of this relationship results from the acceptance of prejudices that alter the perception of the interaction between ecologicaleconomic and cultural changes, as well as their deeper origins and consequences.

\footnotetext{
E-mail address: michel-barbaza@wanadoo.fr.
}

\subsection{State of the question}

\subsubsection{Traditional approach}

According to traditional thinking, the profound cultural changes, which, at the dawn of the new climatic age, disrupted the several thousand year old Magdalenian trajectory, were the immediate result of the adaptation of tools to new natural conditions. This widely accepted explanation has the power of simplicity and does integrate a certain degree of radicalisation. It may, however, be excessively mechanistic.

\subsubsection{New paradigms}

The chronological and spatial relationships between the Upper/ Final Magdalenian, in its various regional aspects and manifestations, and the Azilian, consistently pose the problem of their phyletic relationship, as well as the question of the deeper significance of the modifications of the material culture. The principles ruling these changes were the result of either technological adaptations to new ecological conditions, according to the classic view, or, according to a still largely prospective view, the disaffection of the cultural foundations of Magdalenian society, which were continued into the Tardiglacial period by more southerly nonnative traditions. The effects would have been more or less rapid, depending on the location. It is therefore possible to envisage that, during the very late glacial period, and for reasons that are difficult to specify and which may result from their own internal history, some small communities may have maintained certain contexts and aspects of the Magdalenian tradition. In contrast, other groups would have been open to new influences emerging from the Gravettian heart of the Mediterranean peninsulas. 


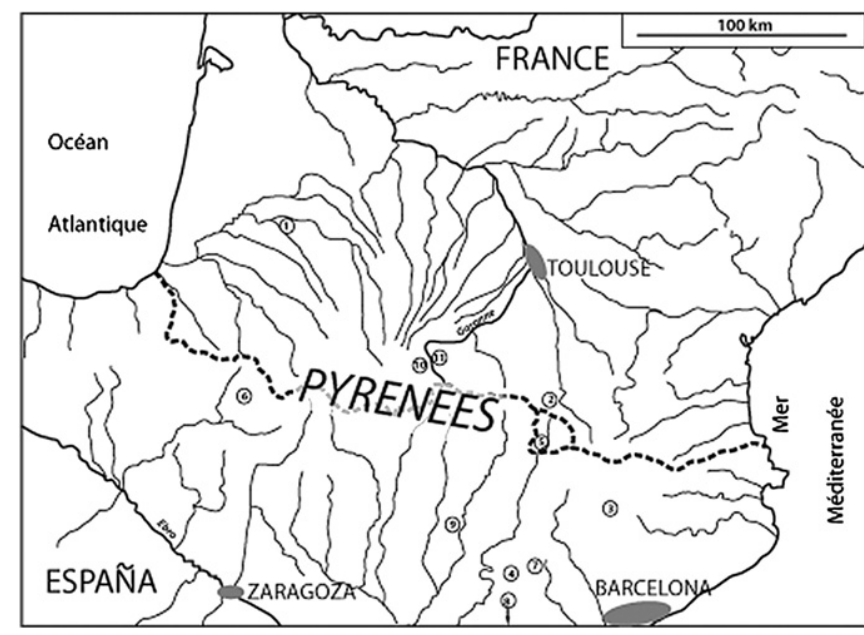

Fig. 1. The Gallic isthmus and Pyrenees. Locations of the main sites mentioned in the text. 1, Abri Dufaure. 2, Abri de Rhodes II. 3, Balma del Gai. 4, L'Hort de la Boquera. 5, Balma de la Margineda. 6, Zatoya. 7, El Moli del Salt. 8, Tossal de la Roca. 9, El Parco. 10, Grotte de Troubat. 11, Palaeolake Barbazan.

The vivacity of the Magdalenian tradition can be appreciated through the evidence from several sites dated from the 12th and 11th millennium BP (Table 1). At Troubat-en-Barousse, in the Haute-Pyrénées department, layer 7 ended a typical sequence of the Upper Magdalenian. It yielded indisputably Magdalenian lithic and bone tools. According to the stratigraphic sequence of the deposit and the chrono-cultural structure established for the whole of the Pyrenean Magdalenian, this level does date to the terminal Magdalenian. However, times had changed! Reindeer were no longer part of the hunted prey and the first snails appeared. The fauna was entirely temperate and composed of a broad spectrum of species: large numbers of salmon, ibex, in line with the mountainous setting, but also forest animals such as red deer and wild boar. Is such a late assemblage of this nature difficult to accept? Recall that, close to and in constant communication with the western and central part of the Pyrenean chain, the Cantabrian mountains offer many examples of occupation levels of the same type, the same chronology, and, above all, resulting from multimillennia-long practices.

At the cave of Gazel in Languedoc, the Magdalenian tradition of stone-working also continued until the 11th millennium BP, while the traditional bone tools were missing and subsistence was based on temperate environment animals. This Epi-Magdalenian assemblage, which maintained the ancient skills over more than a millennium while the environment underwent considerable changes, shows with great clarity the small degree of environmental dependence exhibited by the details of lithic tools. The Mediterranean Spanish Magdalenian shows nothing to the contrary. It is necessary to imagine exceptional resistance to environmental pressure to explain this phenomenon; vehement resistance indeed, as it would have been present, in particular at Gazel, for more than two millennia.

\subsubsection{Set of problems}

Is this not all much more simply a cultural issue? Perhaps the Azilian did not inevitably leave traces in the Magdalenian structures. A tradition may have been able to persist when the human group with which it was associated knew how or was able to preserve cohesion sufficient for its maintenance. What is meant by cohesion? The question is open, but necessarily implies multiple factors, including economic and demographic dynamics, the active supports for a social and cultural life still close to tradition. This consideration leads to a stumbling block in Prehistory, whose unavoidably archaeographical methods, particularly for these distant periods, scarcely allow a demographic or structural approach to human societies. In the central and western Pyrenees, the Upper Magdalenian includes an equally late final phase, which positions the final manifestations of this culture towards the end of the 10th millennium BC. The bone tools, here quite well represented, include harpoons that are sometimes flat but universally clearly Magdalenian in appearance. The associated fauna is of a forest type. The Azilian that sometimes succeeds this period in the deposits appears most often in its classic phase. It was characterised by a lithic industry dominated by microlithic scrapers and backed points, by the "fir tree" silhouetted harpoons of the early 20th century authors, and by painted pebbles: the ensemble dates from the start of the 12th millennium BP and the millennium following (see Straus, 1985, 1986a,b). Was the Azilian, then, earlier in northern France and the neighbouring areas, as has been suggested? This simplification cannot be so easily established by examining some Pyrenean sites which were occupied by 'lithic' Azilian tool makers (microlithic scrapers, backed points, "pièces esquillées") but indubitably predate the classic phase of this "Pyrenean Azilian" culture, characterised by both the above-described equipment and by flat harpoons and decorated pebbles. The early Aziloid or Proto-Azilian, lacking harpoons and painted pebbles, would be contemporary with the last developments of the Magdalenian. The difference between the techno-cultural features of the Upper Magdalenian and Azilian should be mostly matters for cultural determinism rather than due to environmental changes. If the temperate Bölling-Alleröd seems to have occurred at the origin of the shrinkage of the Magdalenian in its major appearances (notably religious rock art), the cold Younger Dryas did not restore its vigour, anymore than it opposed the development of Mediterranean microlaminar facies: Proto-Azilian or Aziloid in the Mediterranean zone of the Iberian Peninsula; Proto-Azilian followed by classic Azilian on the northern face of the Pyrenees, where the Southern influences meet the influences of Cantabria at the beginning of the 11th millennium before the present (Barbaza and Lacombe, 2005; see Table 2).

\section{Environmental data at the extreme end of the Tardiglacial period}

\subsection{Ice cores}

The existence of an Older Dryas period is now challenged in several southern regions (Sanchez Goni, 1996). For this reason, the Tardiglacial period is here considered as a whole formed by the Bölling-Alleröd interstadial and the cold episode of the Younger Dryas. Following the Alleröd, (or GIS-1) situated around 12,000-11,000 BP (Magny, 1995), or between 13,800 and 12,900 cal BP, the Younger Dryas is indicated by anomalies in the isotopic composition of oxygen $\left({ }^{16} \mathrm{O} /{ }^{18} \mathrm{O}\right)$ within ice cores, which show a drop in temperatures of around $6{ }^{\circ} \mathrm{C}$ in less than a century (Grousset, 2001). This event, corresponding to GS-1 (Rasmussen et al., 2006), is approximately dated to between 11,000 and $10,000 \mathrm{BP}$, approximately $13,000-11,700 \mathrm{cal} \mathrm{BP}$. The calibration of ${ }^{14} \mathrm{C}$ dates has been carried out according to the Calib6.0 Intcal09 curve.

\subsection{Palaeobotanical data}

\subsubsection{Marine data}

The continental response to climatic changes appears to have been rapid. Several marine cores measure the influence of the 
Table 1

Calibration of dates used in the text (Calib6.0 Reimer et al, 2004; Intcal09).

\begin{tabular}{|c|c|c|c|c|c|}
\hline Site & Lab \# & Date BP & Context & cal BP $68.3 \%$ & cal BP $95.4 \%$ \\
\hline Dufaure C4base & Ly. 3182 & $12,260 \pm 400$ & Magd. sup & $13,778 / 14,990$ & $13,294 / 15,891$ \\
\hline Dufaure C3 Os de renne & Poznan. 15984 & $12,260 \pm 60$ & & $13,968 / 14,240$ & $13,898 / 14,569$ \\
\hline Dufaure C4 & Ly. 3245 & $12,030 \pm 280$ & Magd. sup. & $13,457 / 14,241$ & $13,338 / 14,965$ \\
\hline Dufaure C4 & Ly. 3181 & $11,750 \pm 300$ & Magd. sup & $13,292 / 13,914$ & $12,934 / 14,543$ \\
\hline Rhodes II C5 & Mc. 996 & $12,300 \pm 150$ & Proto-Azilian & $13,964 / 14,607$ & $13,855 / 14,993$ \\
\hline El Gai C3 & Gif. 95630 & $12,240 \pm 110$ & Proto-Azilian & $13,911 / 14,247$ & $13,820 / 14,664$ \\
\hline Rhodes II F6 & Mc. 997 & $12,100 \pm 150$ & Proto-Azilian & $13,768 / 14,149$ & $13,583 / 14,605$ \\
\hline El Gai C2 & Mc. 2141 & $11,050 \pm 160$ & Proto-Azilian & $12,760 / 13,100$ & $12,636 / 13,242$ \\
\hline Hort Boquera & OxA. 13595 & $12,250 \pm 60$ & Proto-Azilian & $13,968 / 14,222$ & $13,885 / 14,558$ \\
\hline Margineda $\mathrm{C} 10$ & Ly. 4898 & $11,870 \pm 110$ & Proto-Azilian & $13,581 / 13,854$ & $13,438 / 13,952$ \\
\hline Margineda C10 & Ly. 5414 & $11,510 \pm 100$ & Proto-Azilian & $13,263 / 13,455$ & $13,161 / 13,611$ \\
\hline Margineda $\mathrm{C} 10$ & Ly. 4896 & $11,690 \pm 90$ & Proto-Azilian & $13,423 / 13,653$ & $13,342 / 13,759$ \\
\hline Margineda $\mathrm{C} 10$ & Ly. 5413 & $11,560 \pm 230$ & Proto-Azilian & $13,220 / 13,678$ & $12,937 / 13,889$ \\
\hline Zatoya N2 & Ly. 1400 & $11,840 \pm 240$ & Proto-Azilian & $13,418 / 13,927$ & $13,159 / 14,483$ \\
\hline Moli del salt & Gif. 101037 & $11,940 \pm 100$ & Proto-Azilian & $13,683 / 13,922$ & $13,563 / 14,018$ \\
\hline Tossal & Beta. 134880 & $11,820 \pm 40$ & Proto-Azilian & $13,607 / 13,767$ & $13,477 / 13,805$ \\
\hline Parco N1 & OxA. 8656 & $11,430 \pm 60$ & Proto-Azilian & $13,235 / 13,370$ & $13,154 / 13,423$ \\
\hline Parco N1 & GAK. 14192 & $11,510 \pm 170$ & Proto-Azilian & $13,193 / 13,511$ & $13,084 / 13,769$ \\
\hline Parco N1 & OxA. 8657 & $11,270 \pm 90$ & Proto-Azilian & $13,095 / 13,272$ & $12,912 / 13,338$ \\
\hline Barbazan Lacustrine & & $11,590 \pm 270$ & & $13,213 / 13,742$ & $12,876 / 14,026$ \\
\hline Troubat C7b & Ly. 5272 & $11,320 \pm 410$ & Magd. final & $12,744 / 13,581$ & $12,373 / 14,118$ \\
\hline Troubat C7 & Ly. 913 OxA & $11,520 \pm 110$ & Magd. final & $13,256 / 13,476$ & $13,156 / 13,641$ \\
\hline Margineda C8 & Ly. 4407 & $11,320 \pm 120$ & Azilian & $13,101 / 13,318$ & $12,907 / 13,426$ \\
\hline Margineda C8 & Ly. 5418 & $11,230 \pm 170$ & Azilian & $12,925 / 13,283$ & $12,709 / 13,400$ \\
\hline Margineda C8sup & Ly. 5417 & $11,130 \pm 120$ & Azilian & $12,867 / 13,159$ & $12,712 / 13,260$ \\
\hline Dufaure C4 sup & Ly. 2666 & $10,910 \pm 920$ & Magd. sup & $11,321 / 13,751$ & $10,120 / 15,248$ \\
\hline Troubat C6 & Ly. 5275 & $10,770 \pm 100$ & Azilian & $12,576 / 12,747$ & $12,539 / 12,919$ \\
\hline Dufaure C3 & Ly.4223 & $10,310 \pm 270$ & Azilian & $11,708 / 12,540$ & $11,240 / 12,653$ \\
\hline Dufaure C3 & AA. 2478 & $9810 \pm 100$ & Azilian & $11,106 / 11,357$ & $11,065 / 11,614$ \\
\hline Dufaure C3 & AA. 2477 & $9750 \pm 110$ & Azilian & $11,069 / 11,269$ & $10,722 / 11,404$ \\
\hline Dufaure C3 & Ly. 4224 & $9600 \pm 290$ & Azilian & $10,493 / 11,289$ & $10,206 / 11,831$ \\
\hline
\end{tabular}

climate on the vegetation of the Atlantic façade of Europe and the Mediterranean (Sanchez Goni et al., 2000; Sanchez Goni, 2006; Beaudoin et al., 2007; Naughton et al., 2007). Two cores have been carried out in the Gulf of Lion. They show that the BöllingAlleröd interstadial was marked by a resurgence of pine and caducifoliate oak, together with the presence of birch, fir and hazel. In contrast, the Younger Dryas was characterised by a reduction in pine in favour of Artemisia. Birch continued, but hazel and fir were absent. For the Atlantic area, the data concerning the Bölling are unclear. In the Alleröd, there was a notable reduction in Artemisia, grasses and heathers in favour of caducifoliate oak, while pine and birch continued. The Younger Dryas was characterised by the strong presence of birch, and a return of grasses, heathers and Artemisia, to the detriment of pine and caducifoliate oak (Fig. 2).

\subsubsection{Continental data}

Substantial palaeoenvironmental data obtained through numerous continental cores, generally taken from the Pyrenean peat bogs (Jalut et al., 1992, 1996, 1998; Reille, 1990; Montserrat, 1992; Gonzalez-Samperiz et al., 2006; Jalut and Turu i Michels, 2009), is complemented, selectively and from the archaeological sites themselves, by anthracological (wood charcoal) analyses (Barbaza and Heinz, 1992; Heinz and Barbaza, 1998). From the perspective of the pollen record, the glaciolacustrine fill of the Barbazan palaeolake (Haute-Garonne) has provided a very accurate picture of the dynamics of the palaeoenvironment of the mountain valley of the upper Garonne from the end of the glacial period to the present (Andrieu, 1991; Reille and Andrieu, 1995). Very close to Troubat Cave, and at a similar altitude $(450 \mathrm{~m})$, this site has served as a documentary basis for an interdisciplinary project integrating palynology, sedimentology and isotopic data. The results have been substantially compared with the anthracological data. The optimum of the interstadial forest dynamic is dated at Barbazan to $11,590 \pm 270 \mathrm{BP}$ (Andrieu, 1991). The first anthracological phase of Troubat is attributed to this optimum, which corresponds to significant climate warming that promoted the growth of an open forest scrub with Juniperus, Rhamnaceae and Rosaceae. The second phase can be correlated with the climatic deterioration of the Younger Dryas, with a recession of the Juniperus scrub, with a phase of Rhamnus and Rosaceae. At Barbazan, the Younger Dryas was characterised in the

Table 2

Archaeological differentiation between Magdalenian and Azilian traditions.

\begin{tabular}{|c|c|c|}
\hline & Upper and Final Magdalenian & Azilian and Aziloid \\
\hline Chronology & $13,500 \mathrm{BP}=>11,500 \mathrm{BP}$ & $12,500 \mathrm{BP}=>10,000 \mathrm{BP}$ \\
\hline Subsistence evidence & $\begin{array}{l}\text { Ibex, reindeer, red deer (exclusive in late Magdalenian } \\
\text { context). Plentiful salmon. }\end{array}$ & Ibex, red deer, boar, roe deer. Plentiful salmon. Snails increasing. \\
\hline Lithic technology & Bladelets. Bipolar nucleus. "Soft stone hammer" debitage. & Bladelets and small flakes. "Pièces esquillées". \\
\hline Lithic tools & $\begin{array}{l}\text { Burins, scrapers, perforators, backed bladelets, } \\
\text { hypermicrolithic scalene triangles. }\end{array}$ & Microlithic scrapers, curved backed points, some side scrapers. \\
\hline Bone and antler tools & Magdalenian harpoons, apoints. & Azilian harpoons, awls. \\
\hline Art & Cave and portable art. Figurative and naturalistic expression. & Geometric and abstract portable art. \\
\hline
\end{tabular}




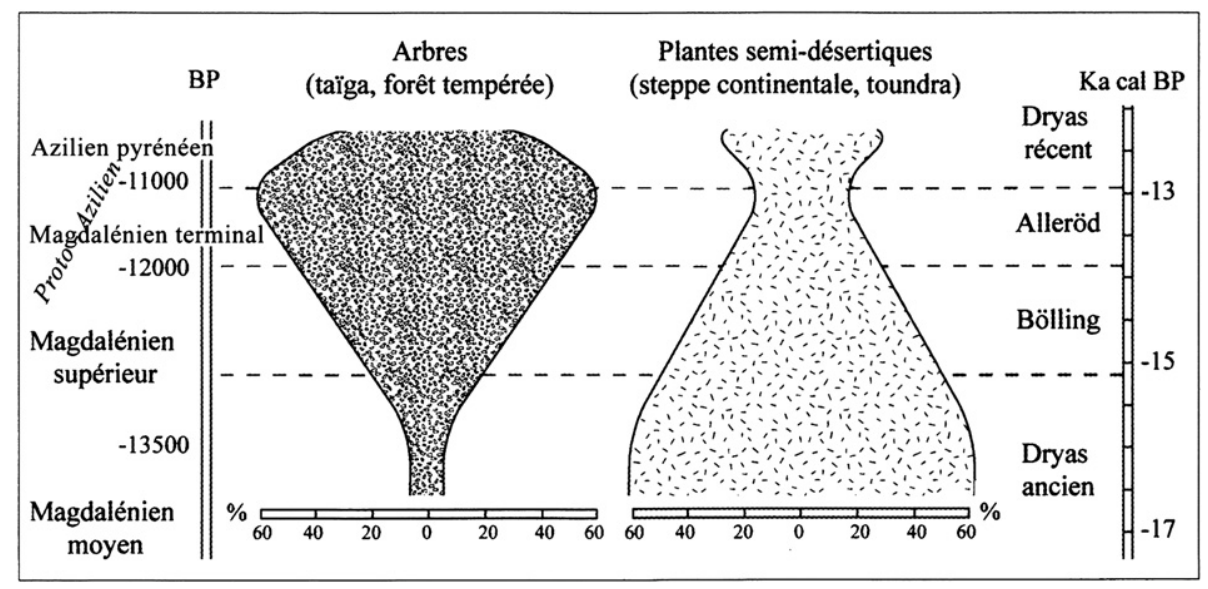

Fig. 2. Dynamics of the vegetation during the Tardiglacial period (after Langlais, 2010).

palynological studies by a new increase in steppe species. Juniperus, Hippophae and Rhamnus were also present. Pine (Pinus) and birch (Betula) were less well represented, indicating an open environment. The Younger Dryas was thus distinctive in southern France between 10,700 and 10,300 BP (Beaulieu et al., 1988). In the western Pyrenees, particularly in the Lourdes basin, birch then receded and steppe species progressed (Artemisia, Ephedra, etc.). The presence of oak (Quercus), which had been stable since the Alleröd, indicates that this (admittedly diverse) genus was not affected by the Younger Dryas cold episodes. The many palynological data obtained in the Pyrenees (Jalut et al., 1982, 1988, 1996, 1998, 1992; Andrieu, 1991; Reille and Andrieu, 1995; Jalut and Turu i Michels, 2009), show that the ${ }^{14} \mathrm{C}$ dates linked to the extension of oak are homogeneous from the west to the east along the north slope of the Pyrenees around 10,300 BP. The start of these curves marks the beginning of the Holocene (Heinz, 2005).

\subsection{Archaeozoological data}

For the northern slope of the Pyrenees, the analyses of the Magdalenian faunas indicate that until the end of the Bölling, the dominant taxa were reindeer, ibex, horse and bison (Delpech, 1989a,b, 1992; Costamagno, 2003; Fosse and Quiles, 2006) (Fig. 3). However, the example of Arancou, in the French Basque country, where red deer hunting was practised on a large scale, has led to the idea that there was either an ecological niche favourable to this species or an absence of reindeer during the "good" season in this region. "Reindeer no longer being available, the hunters were then obliged to turn to prey that were still present, namely red deer and steppe ungulates" (Costamagno et al., 2006, p. 27; see also Geddes et al., 1986; Sommer et al., 2008; Kuntz and Costamagno, in press). In the Alleröd, the forest ungulate group became dominant, indicating climatic improvement. For reindeer, questions under debate relate to the existence of shelters in the Younger Dryas (around 10,500 BP), which would have allowed the maintenance of reindeer, as at Morin (Gironde), la Gare de Couze (Dordogne), Saint-Eulalie in the Lot (Delpech, 1983), or Gazel layer 6 in the Aude (Fontana, 1998; Bridault et al., 2000). Other than these deposits, work carried out in the Cantabrian Mountains (Altuna and Mariezkurrena, 1996), the Alps and the Jura (Bridault et al., 2000), the Languedoc and the Massif Central (Bridault and Fontana, 2003), and the Pyrenees, fix the disappearance of reindeer in these regions

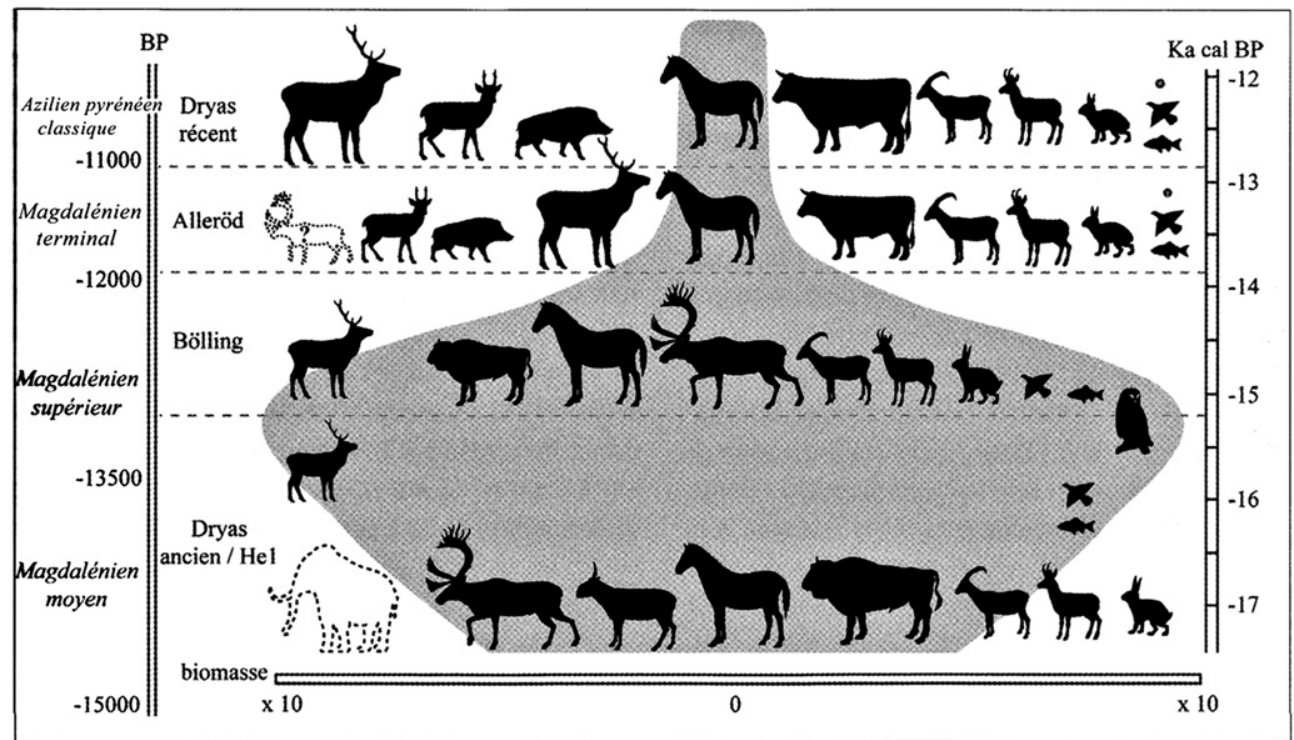

Fig. 3. Hunted game (large and small mammals, birds, fish) in the northern Pyrenees during late glacial periods. Shaded: evaluation of the biomass (after Langlais, 2010). 
at around $12,000 \mathrm{BP}$ (around 13,700 cal BP), or before the last Magdalenian manifestations. In parallel with the exploitation of ungulates, which constituted most of the fauna hunted throughout the Magdalenian, the proportion of small fauna increased. This phenomenon concerns fish (Le Gall, 1992, 1999, 2003), birds (Eastham, 1995; Laroulandie, 2000, 2003) and lagomorphs (Fontana, 2003; Cochard, 2004). The integration of small game in the Magdalenian diet, a phenomenon well known in Spain, took place before the loss of equilibrium (replacement of biocenoses) in the late Bölling and Alleröd. The main change thus occurred between the Bölling and Alleröd (Langlais and Mangado, 2007). The appearance of the first snail shells in the terminal Magdalenian of layer 7 at Troubat illustrates perfectly the diversification of the diet (Barbaza, 1996a).

\subsection{Northern slope of the Pyrenees}

The Pyrenees mountain chain is $430 \mathrm{~km}$ long and has a general east-west orientation between the Atlantic Ocean (Bay of Biscay) and the Mediterranean Sea (Gulf of Lion). Blocking the "Gallic isthmus" with their mass, they constitute today a natural frontier between France and Spain. They are traversed by deep valleys marked by glacial erosion and generally south-north orientations. Their uplift has exposed an axial eruptive zone culminating at $3404 \mathrm{~m}$, on either side of which Mesozoic sedimentary formations form mid-range mountains and hilly areas, traversed by Middle Magdalenian groups from the start of the Tardiglacial. The Pyrenees as a whole and particularly the central area (Ariège and HautesPyrénées departments) are the source of a major network of watercourses that converge towards the Garonne and constitute an exceptional natural communication system between the north of the Aquitaine basin and the Pyrenees. At the extremities of the chain, lower altitudes allow easier access to the northwest (Basque Country) and northeast (Catalonia) of the Iberian Peninsula.

\subsection{Sites}

\subsubsection{Rhodes II rock shelter, Arignac, Ariège}

This shelter clings to the northwest flank of the Tarascon-surAriège basin, which it dominates by $50 \mathrm{~m}$, and occupies a strategic position enabling the observation of the Ariège valley and the steep edges forming it, while benefiting from a favourable exposure. It has a stratigraphic record composed of the remains of successive occupations, preserved by stones spread over the deposits from a neighbouring scree slope. The Magdalenian (Hearths 1-4) is followed by industry characterised by types of tools new to the region, including many circular scrapers, splintered pieces, irregular wide backed bladelets, and Azilian points. Osseous objects are lacking in layer 5, dated to $12,300 \pm 150 \mathrm{BP}$, and in which the classic mountain and forest animal species for these areas are present (ibex, red deer, wild boar and roe deer). The date of "Hearth 6", which also contains an Azilian lithic assemblage, confirms the underlying date of $12,100 \pm 150 \mathrm{BP}$ (Clottes and Simonnet, 1979). Too isolated, apparently too early, too innovative, and thus disturbing, this new way of thinking about the Tardiglacial at Rhodes II has scarcely been taken into account in the literature, despite the quality of the stratigraphy and the relevance of the observations (Simonnet, 1967, 1983).

At Rhodes II, the lithic industry, surprisingly dated to the second half of the 13th millennium BP, constitutes, in its structure and various components, a clear break with the underlying Upper Magdalenian: it represents an early form of Azilian. This is to date the only example of a deposit of this nature located on the northern slope of the Pyrenees, which is worthy of note even if only a pass of relatively modest altitude separates the high valley of the
Vicdessos, which flows into the Tarascon-sur-Ariège basin, and the high valley of the Valira, which links it to the site of la Balma de la Margineda in Andorra.

\subsubsection{La Balma de la Margineda, Sant Julia de Loria, Andorra}

The excavations recently carried out at la Balma Margineda in Andorra, under the direction of Jean Guilaine, fortunately complement and confirm the Tarascon data. La Balma Margineda is a large, open rock shelter in a shale cliff dominating the course of the Valira. Located at an altitude of nearly $1000 \mathrm{~m}$, near the bottom of the valley, the site is surrounded by mountains with elevations of more than $2500 \mathrm{~m}$. The stratigraphy, which is several metres deep, indicates the presence of several Azilian occupation phases (layers 10 to 8 ), followed by Azilo-Sauveterrian (layers 7 and 6 ), and more recent (layer 5 and following) assemblages. The chronological data obtained for this site, consisting of 15 dates for the period of interest, confirm the lessons of Rhodes II, which has a similar Azilian sequence. There is no underlying Magdalenian, however. The first "Azilian" occupation (layer 10, dated to around 11,200-11,800 BP) has evidence of the production of bladelets on the edges of thick flakes and, in a marginal fashion, prismatic debitage from two striking platforms (Lacombe, 2008). The exclusively lithic tools are composed of traditional elements from the Pyrenean Azilian (short scrapers on flakes, splintered pieces, spindle-shaped backed points), which are succeeded by a second phase in which there are flat harpoons (layer 8), dated, as in layer 6 at Troubat, to around $10,500 \mathrm{BP}$, or the Younger Dryas (Barbaza, 1996a). These are the same industries and the same chronology referred to above, attesting to the presence of an early form of Azilian at the very beginning of the 12th millennium (Barbaza and Martzluff, 1995; Barbaza and Lacombe, 2005; Barbaza, 2008; Guilaine et al., 2008).

\subsubsection{La Balma del Gai, Moia, Barcelona province, Catalonia}

La Balma del Gai is located at an altitude of nearly $750 \mathrm{~m}$ on the plateau of Moia, $100 \mathrm{~km}$ north of Barcelona. The site consists of large sedimentary deposits protected by a rocky overhang around $15 \mathrm{~m}$ long and with a variable width of up to $5 \mathrm{~m}$. The faunal remains are very abundant, including rabbit bones (Oryctholagus cuniculus), which must represent (in number) a very high percentage of the animals consumed. Also present were some remains of cervidae, small carnivores, very numerous remains of other small animals (rodents, birds, batrachians, insectivores, etc.) and a few rare remains of ibex. Snail shells (Cepaea nemoralis) were present in large quantities within all of the archaeological layers, from top to bottom. The middle horizon (MC-2141: $11,050 \pm 160 \mathrm{BP}$ ) (Barbaza, 1981, 1989) and the lower horizon (Gif95630: 12,240 \pm 110 BP) (SERF study, Petit-Mendizabal, 1998), may contain industries originating from a relatively early phase of the Epipalaeolithic (Barbaza, 1984). These largely microlithic tools are dominated by short scrapers on microlithic flakes, including some with shouldered fronts, followed numerically by splintered pieces and backed armatures (bladelets and points).

\subsubsection{L'Hort de la Boquera, Margalef, Tarragona, Spain}

The site of l'Hort de la Boquera, excavated under the direction of P. Garcia-Argüelles and J. Nadal of the SERF, is one of the group of rock shelters of the Montsant valley in Priorat, which includes several sites, in particular, between the villages of Margalef and La Bisbal: l'Hort de la Boquera, Filador, Colls or l'Hort d'en Marquet (Fullola, 1990). The geological study of the site has revealed four sedimentary levels (Bergada, 1998). The AMS date recently produced from a sample originating from the excavation (12 $250 \pm 60 \mathrm{BP}$ ) is now accepted (Garcia-Argüelles, in Langlais, 2010). Notable among the technico-economic characteristics of the lithic production at la Boquera is the strictly local raw material 
provisioning, despite a mediocre aptitude for blade production, low technical investment and the use of stone hammers. The study shows a high degree of typological monotony in the assemblage, with domination of the scraper and backed point pairing, the presence of some truncated blades, backed knives, bilaterally notched blades and, finally, by the extreme scarcity of burins (Garcia-Argüelles, 1993). L'Hort de la Boquera belongs to a technocomplex that evokes fairly accurately the Mediterranean microlaminar Epipalaeolithic; a perfect candidate for the paternity of the Proto-Azilian (Barbaza, 1981), of the Sant Gregori type (Fortea-Perez, 1973).

\subsubsection{Other sites}

Several Spanish sites briefly mentioned here have very similar situations to those above. Among these should be mentioned in particular the deposit at Zatoya (Navarra), whose level II, dated to $11,840 \pm 240$ BP (Ly 1400), offers a clearly Aziloid lithic industry with large numbers of scrapers, retouched blades and backed points (Barandiaran and Cava, 1994). A very similar situation exists in level I, Epipalaeolithic with backed points, of the Parco cave, dated to $11,510 \pm 170$ BP (GAK 14192), to $11,430 \pm 60 \mathrm{BP}$ (OXA 8656) and $11,270 \pm 90 \mathrm{BP}$ (OXA 8657) (Garcia-Argüelles et al., 1999). This situation is also present in the deposit of Moli del Salt (Vimbodi, Tarragona), dated to $11,940 \pm 100 \mathrm{BP}$ (Gif-101037) (Vaquero, 2004) and also to the south in the Tossal de la Roca shelter (Alicante), where at least level I belongs to this horizon and is dated to $11,820 \pm 40 \mathrm{BP}$ (Beta 134880) (Cacho et al., 1983; Cacho, 1989; Kozlowski, 1989, pp. 474-475).

\subsubsection{Abri Dufaure, Landes}

Abri Dufaire belongs to the group of Magdalenian and Azilian deposits situated at the foot of the Pastou cliff at Sorde-l'Abbaye (Landes), at the southern extremity of the Aquitaine basin, around $30 \mathrm{~km}$ from the northern border of the Basque Pyrenees. The Pastou deposits represent a residential complex that is geographically complementary to all penecontemporaneous piedmont sites: Lourdes, Arudy, Aussurucq and Isturitz (Straus, 1986a,b).

The Abri Dufaure rock shelter per se was entirely excavated in 1900 , but a series of surveys followed by methodical excavation work carried out on the slope between 1980 and 1984 enabled Lawrence Straus to uncover an area of successive pebble pavements, similar to those at Duruthy, situated $230 \mathrm{~m}$ to the west. The main objective of this operation was to compare the chronostratigraphic sequence and, above all, the information on the paleoenvironments, faunal, industrial and structural content of Dufaure with those of Duruthy and other Tardiglacial Pyrenean sites. One of the main theoretical aims of this research was to test the hypothesis of R. Arambourou and F. Delpech according to which the Pastou cliff was used as a residential site during the cold season, by mobile groups of Magdalenians whose subsistence depended to a large extent on hunting reindeer, which in turn migrated between the summer pastures in the Pyrenees and the low winter grounds in the south of the Aquitaine (Arambourou et al., 1978; Delpech, 1989a,b). This excavation also sought to confirm the survival of reindeer after the Alleröd and until the start of the Holocene, as was suggested by the restricted sample of reindeer remains from the Azilian layer at Duruthy. The research project was generally oriented towards the study of the changes in human adaptations during the Tardiglacial and early Postglacial periods.

Despite the great difficulty of the excavation, due to the particular conditions of the deposit on a talus slope, considerable effort was made in the analysis of the processes of formation and disturbance of the site, and in the search for habitat structures within an area of around $25 \mathrm{~m}^{2}$ of the in situ deposits. ${ }^{1}$ The stratigraphy of a maximum thickness of $2 \mathrm{~m}$ corresponded closely to that of the Magdalenian and Azilian deposits of Duruthy.

The Dufaure sedimentological, palynological and palaeontological analyses confirm the sequence from Duruthy, and provide additional data on the environmental fluctuations during the Dryas I, Bölling, Alleröd, Dryas III and Preboreal periods. The flourishing of the Azilian "culture" clearly corresponded to the substantial reforestation of the Pyrenean region. The archaeozoological studies of mammal remains indicate the existence of a relatively diversified animal exploitation model in the Middle Magdalenian and the Azilian, with much more specialised reindeer hunting in the terminal Magdalenian. However, red deer became increasingly significant in the upper parts of layer 4, and dominant in layer 3 (Altuna and Mariezkurrena, 1995).

The Middle Magdalenian (layer 6, dated to approximately $14,600 \mathrm{BP}$, and layer 5, dated to between 14,000 and 12,700 BP), was succeeded by an Upper Magdalenian (layer 4 dated to between 12,300 and 11,000 BP; layer 4 base - Ly-3182: 12,260 $\pm 400 \mathrm{BP}$; layer 4 - Ly-3245: $12,030 \pm 280 \mathrm{BP}$; layer 4 - Ly-3181: $11,750 \pm 300 \mathrm{BP}$; layer 4 top: Ly-2666: $10,910 \pm 220 \mathrm{BP})$. This horizon was formed of a dozen levels of paving composed of closely fitting pebbles, with clear hearth zones and distinct areas of activity. The lithic tools were dominated by backed bladelets and included characteristic tool types of the terminal Magdalenian, such as Lacan burins, Laugerie-Basse points, Hamburg points and Azilian points. Rare Magdalenian harpoons are present. This Magdalenian assemblage was overlain by an Azilian level (layer 3, dated to between 10,300 and $9600 \mathrm{BP}$; Ly-4223: 10,310 $\pm 270 \mathrm{BP}$; Ly-4224: $9600 \pm 290$ BP; AA-2477: $9750 \pm 110$ BP; AA-2478: $9810 \pm 100$ BP), which yielded an assemblage of lithic tools characteristic of the Azilian (several small scrapers and Azilian points) and a faunal assemblage that included a few reindeer remains, together with red deer. However, recent dating carried out directly on a reindeer bone from layer 3 (Poznan-15984: 12,260 $\pm 60 \mathrm{BP}$ ) suggests that the remains of this species are intrusive from later deposits (Costamagno et al., 2009). The idea of a high-altitude refuge zone that was late and favourable to reindeer during the Bölling-Alleröd interstadial (Delpech, 1989a,b), together with the concept of a recolonisation indicating the return of the cold during the Younger Dryas, may be undermined by this single date, although it confirms the probable disappearance of this species in the Pyrenees at the beginning of the Alleröd. This situates the loss of equilibrium at around $12,000 \mathrm{BP}$, with the increasing rarity, followed by the disappearance of Pleistocene ungulates, and the redeployment from Spain of forest species, which now included roe deer and wild boar alongside the red deer which had dominated since the start of the interstadial (Straus, 1992). This population, already truly Holocene in the original sense of the word, would not be challenged at a later date. The ungulates' dental cementum annuli, the indications from the fusion of long bones in migrating birds, and even the evidence of mole behaviour - all indicate occupation of the site in the cold season. An interesting difference between Dufaure and Duruthy is the almost complete absence of salmon and the rarity of harpoons at the first site, while they are present in abundance at the second. Straus put forward the hypothesis that the residential periods at Dufaure began at a later stage of the autumn than at Duruthy, when the salmon had already finished swimming up to their Pyrenean

\footnotetext{
1 Straus (1995, p. 73) states that "Dufaure is not Pincevent (... but that) the duty of Archaeology is to employ precious sites to interpret - with prudence - the activities which were carried out there, and their role in regional adaptive systems". This displays modesty and caution exemplary of the author and to which everyone should subscribe.
} 
spawning grounds. The petrographic analysis of flint at Dufaure shows strictly local origins in both Magdalenian and Azilian times (Seronie-Vivien, 1995). Four engraved plaques and pebbles were found in 1900 in the terminal Magdalenian and Azilian layers by Breni and Dubalon (D'Errico, 1995).

Research at Dufaure has confirmed the hypothesis that the Pastou cliff was a very important site of human occupation and reindeer hunting in the cold season during the Tardiglacial period. General similarities can be detected among the adaptive systems of the final Palaeolithic in the Pyrenees and Cantabrian mountains, as do occasional differences compared to other Magdalenian and Azilian deposits of the Pyrenees, particularly in the greatly varying degree of dependence on reindeer. The author of the Dufaure works emphasises, not without reason, that it was during the Dryas III period that the technological transition from the terminal Magdalenian to the Azilian took place at Pastou, pointing out that there is, "therefore an interval between the industries: Terminal Magdalenian in the Alleröd despite temperate and relatively wooded conditions; Azilian in Dryas III despite cold and relatively open conditions" and remarking that "technological changes in subsistence and organisation are not produced immediately at the time of the great climatic changes" (Straus, 1995, p. 263, translated). At the same latitude in Spain, human subsistence was already, and had long been, much more diversified, and red deer, the main game, simply continued its domination in wooded conditions in the same way it had dominated the grasslands and heaths in the glacial period. With chronological and regional forms presenting some original aspects, the Cantabrian lithic and bone industries show true Magdalenian characteristics, even up to the point of their final manifestation (César Gonzalez Sainz's Phase VIII; Gonzalez Sainz, 1995, 1989). The archaeological phenomenon of the Azilian is nonetheless considered at Dufaure as "an evolution of the adaptive system" (...) provoked "by climatic, plant and faunal variations at the end of the glacial period"... (Straus, 1995, p. 274, translated).

\subsubsection{Troubat Cave, Hautes-Pyrénées}

The Moulin cave-shelter at Troubat (Hautes-Pyrénées) is situated in the Mesozoic limestone deposits forming the northern border of the Pyrenean massifs. It is located at an altitude of $541 \mathrm{~m}$ near the outlet of the Ourse basin onto the Garonne piedmont. The site has the form of a small cavity preceded by a cliff front forming a shelter, with an area of $100 \mathrm{~m}^{2}$, and the 'porch' area contains the main archaeological deposits. The stratigraphy has a total thickness of more than $4 \mathrm{~m}$ and indicates, in the current state of knowledge, various Magdalenian occupations without any major discontinuity, starting from an early stage of the Middle Magdalenian with Lussac-Angles type spear points (layer 13) to a final stage of the Upper Magdalenian (layer 7) dated to the middle of the 11th millennium from values, for layer $7 \mathrm{~b}$ exterior, established at: $11,320 \pm 410 \mathrm{BP}$ [Ly-5272], and 11,520 \pm 100 BP [Lyon-913 (OXA)], for layer 7 interior from a single large charcoal fragment. The immediately underlying Azilian layer 6 has been dated to $10,770 \pm 100 \mathrm{BP}$ (Ly5275). This stratigraphic unit yielded abundant lithic and bone artefacts together with painted pebbles, all comprising the now classic Pyrenean Azilian reference assemblage. At Troubat, the biostratigraphical individualisation established for the whole of the sequence demonstrates a transformation of fairly severe conditions into considerably milder ones, with punctuated discontinuous transformations over a long period, which were recorded by the environment during the Tardiglacial and early Postglacial periods. The temperate animal species became exclusive starting in the upper levels of layer 8 (Upper Magdalenian). This transformation seems to accord completely with the pattern of change in large mammal fauna in Aquitaine at the extreme end of the Pleistocene (Delpech, 1992; Costamagno, 2005). The first snail shells appear at the base of layer 7 in association with terminal Magdalenian artifacts. The study of the anthracological remains has enabled the organisation of the vegetation into successive phases, with two main periods following a phase marked by severe conditions, of a purely Tardiglacial type, during the formation of layers 10 to 8 . Layers 7 and 6 are characterised by heliophile species of montane or sub-alpine type, including juniper, sea buckthorn, willow and birch, indicating a rather open vegetation and a still relatively severe climate, in accordance with the mountainous environment of the site. Layer 6 does not show any significant change other than the appearance of the first oaks and maples. This floristic assemblage can be compared to that recognised in the Epi-Magdalenian sequence of the roughly contemporary Gazel Cave (Aude). At Troubat, the dynamic is confirmed and clearly accentuated in layer 5 and the upper layers, entering into a second phase marked by clear increase of Norway pine, caducifoliate oak and hazel. Here there is a hill-type vegetation, butwith mountain influences (Barbaza and Heinz, 1992; Heinz and Barbaza, 1998; Heinz, 2005).

This evidence corresponds well with the palaeoenvironmental contexts of the Tardiglacial Bölling-Alleröd interstadial (Andrieu, 1991). However, it is impossible to achieve a greater degree of chronological accuracy within this episode. Only the Azilian layer 6 can be situated with certainty during the Younger Dryas cold phase. The remarkable abundance of animal remains of all types shows that the successive occupants of the site were able to benefit from the full diversification of resources offered by the altitudinal zonation of the natural context in which it was situated. Reindeer is absent from the base of layer 7 (Terminal Magdalenian) and is also lacking from layer 6 (classic Pyrenean Azilian); these two levels were very similar, with red deer dominant, plus ibex, wild boar and roe deer, whose frequency was nonetheless reduced during the Younger Dryas (Martin, 1994). Finally, from the start of the Upper Magdalenian (layer 8), salmon fishing seems to have been the subject of intense activity.

The phenomenon of Azilianisation is perceived in the site through the artefacts recovered from layers 7 and 6 . Layer 7, situated between the Upper Magdalenian with elongated scalene triangles and harpoons, and the classic Pyrenean Azilian with backed points, flat harpoons and painted pebbles, is attributed to a terminal Magdalenian, dated to the Alleröd (Barbaza, 1996a, b). The bone industry, particularly harpoons, is typically Magdalenian. The lithic equipment is also clearly Magdalenian in its general composition, but shows some very minor Azilian characteristics, with speculative origins: a minor Magdalenian developmentn, evidence of the passage of an Azilian group, or relative stratigraphic independence of layers 7 and 6 ? In terms of armatures, there are many simple, truncated or denticulated backed bladelets and hypermicrolithic scalene triangles, well known from pyrenean Magdalenian contexts, accompanied by a few Azilian points (Fig. 4). The burins and borers largely dominate the scrapers, among which are some made on small flakes. The fauna consumed indicate an environment deprived of Arctic species (Costamagno, 1999, 2005). Backed points being very rare in layer 8 (Upper Magdalenian) and numerous in layer 6 , the lithic assemblage of layer 7 indicates a discreet transition between the Magdalenian and Azilian, which does not succeed in masking - in this site - a rapid succession between a Final Magdalenian, whose mutation process was at best barely initiated, and a fully developed Azilian (Barbaza, 1996a, p. 318). The existence of structured hearths within this stratigraphic unit and the coherence of the faunal data support the hypothesis of a terminal Magdalenian in the Alleröd. The distributions shown through the analysis of the artifacts from the site of Troubat indicate a very large majority of raw materials procured from local or nearby sources. Whatever its nature, this flint was collected either near the primary sources or in the alluvial deposits of watercourses. 



Fig. 4. Azilian tools of Troubat cave. 1-10: short scrapers. 11-21: Azilian points. 22-25: “Pièces esquillées". 26: large scraper

In the same manner, a relatively large proportion of the flint originated from Tertiary limestone, whose first sources are also encountered not far east of the site. This series is completed by a range of more or less siliceous stones available locally, but rare, stone materials with a distant origin are also present. The principal image is of an intensive exploitation of a limited territory, but the minimal proportion of allochthonous flint in the assemblage indicates long displacements from which the group returned to the site with only a few traces. For example, this may be the status of the Senonian and "Fumelois" flints from layer 6 at Troubat. "We are no longer looking at the reduction of a territory of passage, but of $a$ territory of subsistence under the effect of a more attentive use of resources (and perhaps one which lasts for longer) in a relatively restricted geographical space" (Lacombe, 1998a, b). As a general rule, the nodules exploited are often of small dimensions. Overall, the debitage seems to favour the fabrication of laminar and lamellar flakes to be transformed into various tools, mainly backed points. There was also, however, an independent "chaîne opératoire" for the production of short flakes to be transformed into domestic tools, such as scrapers, retouched flakes and splintered pieces. This 
can be seen in the rather unusual exploitation of small nodules using a principle comparable to a discoid method. As for the lamino-lamellar flakes, an overwhelming proportion of bladelets is the key point to retain. The few blades are generally present only in a modified form and do not seem to have been knapped on the site itself. The bladelets were produced from generally unproductive cores. This results directly from a lack of core preparation, along with the method used to extract these products. This latter generally consisted of the use of a single, highly inclined, plain striking platform, combined with significant abrasion of the overhang to define the points of impact. Crests, most often partial and rare, seem to have been the only solution to correct the problems of longitudinal convexity. In addition, since the flaking surfaces were often quite rectilinear and wide, many hinges were produced during debitage. On the products themselves, the generally small or crushed butts and clearly marked percussion bulbs, along with the characteristics just described, indicate the use of soft stone hammers (Barbaza and Lacombe, 2005; Lacombe, 2005). The retouched objects included in the category of tools also obey the general rules for the assemblages comprising the microlaminar technocomplex: the same blanks, and thus the same tools of generally small dimensions, as well as the same internal proportions, with an overwhelming domination of backed objects on bladelets (a representation in excess of $60 \%$, enabled by systematic water-sieving with a fine mesh). This is true for the Final Magdalenian, with its backed bladelets and a few backed points (accompanied by a few specific points with a more northern European character, including one shouldered point), and for the Azilian, with backed points of which the vast majority are spindle-shaped (symmetrical along the longitudinal axis), complemented by a few backed bladelets slightly larger than their Magdalenian equivalents. Burins, which are common in the Final Magdalenian, have completely disappeared, while splintered pieces are numerous. The main difference between the Pyrenean Middle and Upper Magdalenian, on one hand, and the other lithic facies of the end of the Tardiglacial period, which share the characteristic of lithic tools of small dimensions (a phenomenon that cannot be attributed to a lack of flint materials), is the importance accorded by the former to bone tools (Fig. 5), an ancient practice whose consequence was to transform the common base of the Mediterranean "microlaminar" phenomenon. Another significant opposition can be seen in the quantitative and qualitative differences in "artistic" expressions, which create a profound rupture in practices and mentalities by renewing ancient traditions, long overshadowed in the extreme west of Europe by the Magdalenian tradition (Barbaza, 1996a,b, 1997, 1999; Barbaza and Lacombe, 2005).

\subsubsection{Bourrouilla Cave, Arancou, Pyrénées-Atlantiques}

This site is contained within the small cavity of Bourouilla in the municipality of Arancou, approximately $9 \mathrm{~km}$ from the Pastou cliff. This cave of $12 \mathrm{~m}$ by $3 \mathrm{~m}$ contains a Tardiglacial stratigraphic sequence with three main archaeological assemblages, beginning with an Upper or Middle Magdalenian (assemblage C), an Upper Magdalenian with harpoons (assemblage B) and an assemblage ("A") within which there are very numerous broken snail shells and a relatively scarce lithic industry, at one time attributed to the Azilian (Dachary, 2002), and later to the terminal Magdalenian (Dachary, 2009). The tools from the three levels that constitute this horizon did not change significantly relative to the underlying layer B1, attributed to the Upper Magdalenian. Nonetheless, spindleshaped backed points obtained from a specific debitage method done with soft stone hammers are well attested alongside the large blades. The absence of cores prevents an accurate determination of the production phases of the blanks from which these points were made. The fauna is dominated by more temperature species such as red deer and roe deer, while reindeer are rare and their presence even questioned (Costamagno, 2005). No bone industry is documented as yet. This assemblage is similar to the terminal Magdalenian of layer 7 at Troubat.

\subsubsection{Gazel Cave, Sallèles-Cabardès, Aude}

This cavity is located on the southern flank of the Montagne Noire, facing the Aude plain near Carcassone. The thick deposit, which contains the remains of a habitation extending from the Middle Magdalenian to the Final Neolithic, reveals traces of an occupation (layers 6 and 5) dated to the Younger Dryas (around 10,500 BP), and separated from the Middle Magdalenian of layer 7 by a calcareous level. Due to the presence of several backed points (including backed points with a truncated base), the lack of bone industry and art objects, and the existence of new ecological conditions (shown by exclusively temperate fauna), the term "EpiMagdalenian" is preferred to that of Final Magdalenian (Sacchi, 1986).

\section{Contexts between culture and nature}

3.1. Technocomplexes, Magdalenian survivals, “Azilianisation”, and the Azilian between Rhône and Ebro

\subsubsection{North of the Pyrenees}

Around 12,500 BP, during the Bölling, the whole of western Europe saw the development of lithic industries dominated by backed points and short scrapers. They are variously designated as the Federmesser, Azilian, microlaminar Epipalaeolithic, Valorguian, etc. At the same time, osseous industries, which are highly abundant and diversified in the Magdalenian, lost their importance, with contrasting regional situations ranging from total absence to relative abundance. This "Azilianisation" process, detectable in the archaeological record, seems to have coincided with the recomposition of the faunal context at the end of the Tardiglacial period. However, the Upper Magdalenian of the northern slope of the Pyrenees seems to have survived until the latter part of the BöllingAlleröd interstadial. The strict interpretation of these "Azilianizing" innovations as adaptations to new ecological conditions is therefore not satisfying and leads to the suggestion of a continuation of the Magdalenian within an environment totally devoid of glacial species, in particular reindeer. An Epi-Magdalenian period has been identified in Gazel Cave, layers 6 and 5 (Sacchi, 1986), while a terminal Magdalenian dated at Troubat, layer 7 to the Alleröd (Barbaza, 1996a), is also proposed in Bourrouilla A (Dachary, 2002).

\subsubsection{South of the Pyrenees: the early Epipalaeolithic of Mediterranean Spain}

According to a recent presentation by Mathieu Langlais, the lithic material of Hort de la Boquera reveals an integrated laminolamellar production supplying blanks for both domestic tools and backed points. The method employed differs considerably from those of the classic Magdalenian technical tradition. During the Bölling (approximately 12,500-12,000 BP), in parallel with the last gasp of the Upper Magdalenian, an Epipalaeolithic industry developed in Catalonia, dominated by rectilinear backed points with a truncated base and scrapers, and following very different technical traditions than those of the Magdalenian (Langlais, 2010). This data appear to support the "Tardigravettian" hypothesis (Barbaza, 1984, 1989). In this context, it was explicitly envisaged that the traditional internal and linear evolution of the Magdalenian was in competition with an external dynamic whose origin could be found in the early Mediterranean Epipaleolithic, and which has many Epigravettian features in terms of its as technical traditions (Montoya, 2004). With regional variations, the whole of 

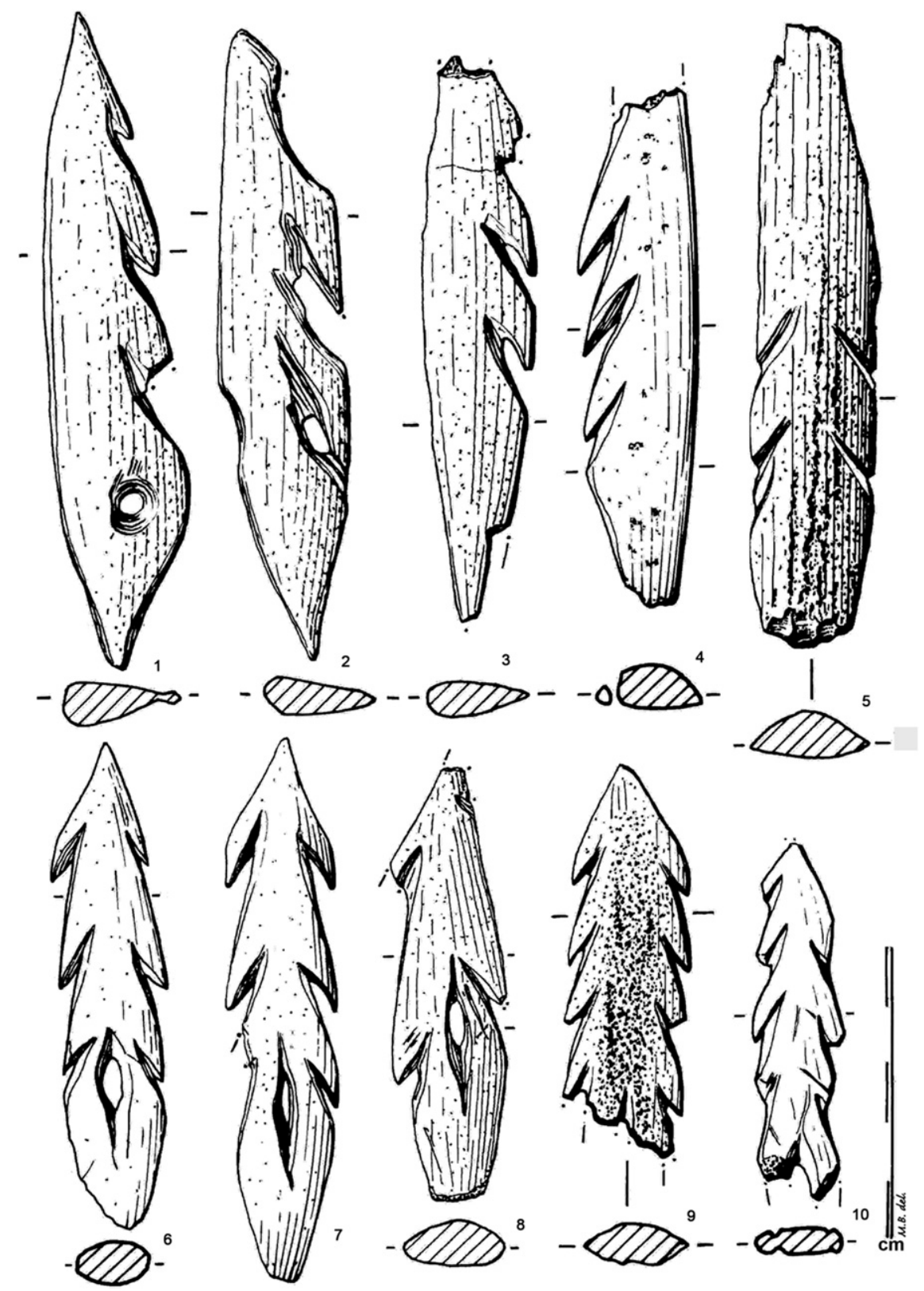

Fig. 5. Azilian harpoons of Troubat cave.

this Catalonian early Epipalaeolithic prolonged the characteristics of microlaminar backed point complexes, studied in particular by Vilaseca-Angura (1973), Fortea-Perez (1973) and Aparicio-Perez (1979) between Catalonia and Valencia, but also well beyond, throughout the entire zone of influence of the Mediterranean climate, from Catalonia to Portugal.

\subsection{Symbolic expressions}

Cave art sanctuaries, whether small or large, disappeared with the dissolution of the Magdalenian at the dawn of the new climatic order. "The last engraved animals faded away with the melting of the Magdalenian into the Azilian which prolonged it, in a mental environment that came to resemble the natural environment", wrote Leroi-Gourhan somewhat obscurely in 1965. In fact, the causes are uncertain, though they are inevitably linked, in one way or another, directly or not, with the change in environmental conditions. But the time of the great hunt ceased neither in the Final Magdalenian, when reindeer seem even to have been over-represented in parietal and portable art relative to the potential fauna (Tosello, 2003), nor in the Azilian, during which the former hunting practices continued, despite a changed mental universe. It was therefore not the abandonment of this activity that led to the disappearance of Palaeolithic art, but more certainly changes in the way in which it was practised and the place assigned to animals in the collective imagination. These reasons, impossible to grasp by means of archaeology per se, are rooted rather in the transformations of the modes of social cohesion, in the profound mutation of mentalities and ideologies, which gave way, either little by little or all at once, in the face of new ways of being in a new world. After the Magdalenian, animal art nonetheless survived for some time, though its occurrences are very localised; they are uniquely 
attested by portable artefacts donned with mostly non-figurative motifs, signs and outlines. The figurative tradition did not disappear completely, but became exceptional. More than a degeneration, the quantitative impoverishment indicated by the extreme simplification of the outlines may have been the culmination, perhaps even the glorification, of a general symbolism isolated from all figurative support. The abstract and often geometric representations thus materialized, in a manner that is trivial and lacks great significance to us, a manner of representing particularly elaborate abstract concepts, whose graphic translation appears to our eyes as no more than simple decoration (Fig. 6). Only a few discrete and dispersed items of disparate information emerged on the European scale. It is significant that in the south-west of France, several centres of creation may have prolonged, in various guises, what we consider as the last expressions of Palaeolithic art.

The most striking example is that of Mas d'Azil (Ariège), an immense tunnel cavern hollowed out by the Arize River and the most representative site of Azilian art in the Pyrenees and Cantabrian mountains. Only a dozen engraved pieces were found here, compared to more than 1400 painted pebbles (Fig. 7), which are fundamental elements of the classic Pyrenean Azilian, alongside the characteristic lithic industry and numerous harpoons. The eponymous site has no equal in its variety of simple decorative themes - transverse lines or dots - or more complex ones with broken or undulating longitudinal lines, curves, chevrons, Greek borders, with cruciform interlaced lines or divided motifs. Among several representative sites between the Mediterranean and Atlantic are the cave of Crouzade at Gruissan (Aude), the Abri Rhodes II or the Abri du Trou-Violet (Ariège), each associated with a human burial, or the once-eponymous deposit of La Tourasse in Haute-Garonne, the Moulin cave-shelter at Troubat and the Abri Dufaure. However, the Azilian was also the epoch during which curious animal figures were produced, often on simple fragments of bone diaphyses. Far from approaching, more or less willingly, the "realism" of the Magdalenian, as do the pebbles from the Abri Murat, these representations express a style that was free from any form of naturalism beyond the indication of species. A horse or an aurochs can be recognised, but the concern for particular notation or for well-observed detail has completely disappeared. The rigid, massive bodies surmount abnormally short legs. Specific attributes such as horns are very conventionally expressed in frontal view. This is no longer the Magdalenian style. The example provided by La Borie del Rey at Blanquefort-sur-Briolance is particularly
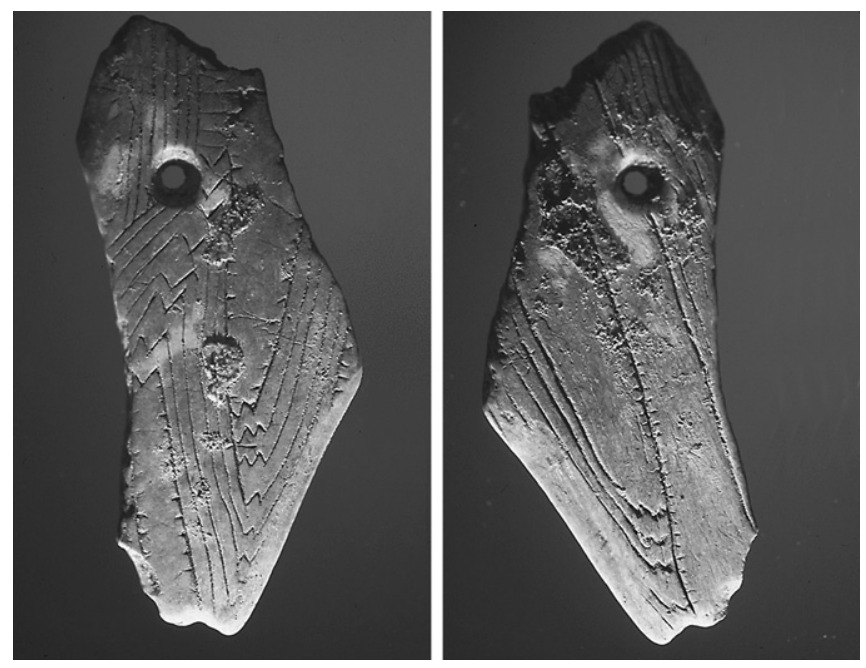

Fig. 6. Engraved Azilian pendant. Troubat cave, layer 6.

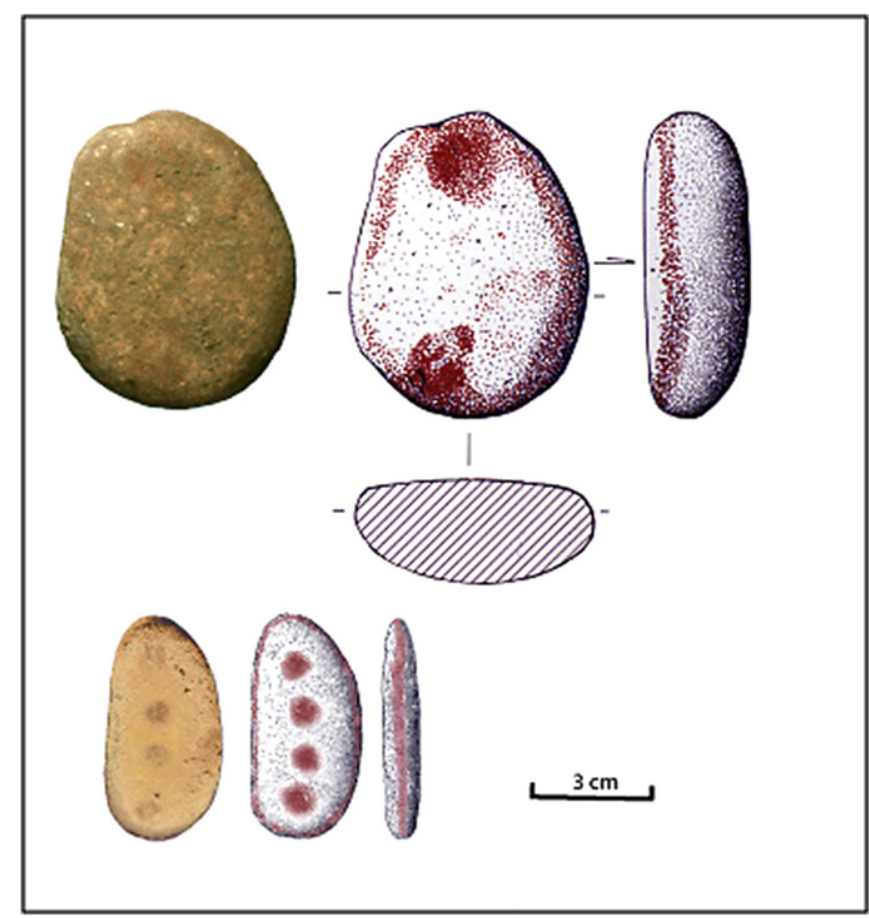

Fig. 7. Painted pebbles. Troubat cave.

demonstrative. It evokes the Gravettian tradition as it is attested in the "Mediterranean province". The body is expressed with short incisions, grouped in hatchings, crosses or zig-zags, arranged with no concern for realism or a model. The magnificent horse from Pont-d'Ambon at Bourdeilles includes all these peculiarities. The representations from the Gouy Cave in Seine-Maritime, which presents most of these characteristics, may also have belonged to this same chrono-stylistic context. Some pieces are more surprising, such as the magnificent composition realized at Troubat by engraving on a bone pendant (Barbaza et al., 1998; Barbaza, 1999).

\section{Conclusion: the Azilian Pyrenees, between the Mediterranean and Cantabrian borders}

It now seems possible to reconsider the north Pyrenean Azilian in the context of Azilian Vasco-Cantabrian sites (FernandezTresguerres, 1995; Straus, in this issue) and the long recognised microlaminar sites (excluding the Magdalenian) of the Iberian peninsula (Fortea-Perez, 1973). On closer consideration, it seems that there would be the material for a broad research project on the sort of "nebulous" techno-typology that constitutes the various Azilian facies. The foundations of this research would be based on the study of cultural change and, even more so, on the profound causes which led to that change. Such are the elements of reflection that have led to the question of the degree of originality of the Pyrenean Azilian, the only geographic facies of the late Palaeolithic that deserves, other than by mere custom, its designation as Azilian among the range of cultures of the end of the Tardiglacial period. Towards the end of this Tardiglacial period, we are therefore in the presence of a set of cultures (late Upper Magdalenian and EpiMagdalenian face to face with Epipalaeolithic, Tardigravettian, Proto-Azilian or Early Azilian), which had quite different characteristics, at least in appearance. In reality, considering only the lithic tools, each of these (Middle-Upper Magdalenian included) may have been integrated into the same polymorphous "microlaminar" 
technocomplex. Beyond the cultural conservatism of typologies, which is sometimes accentuated by the variable inclusion of osseous materials, this ensemble is characterised by small lithic objects, the increasing use of local siliceous stones - which does not exclude more distant procurement sources - and by the fabrication of bladelets via "soft" stone hammers.

In parallel with the Magdalenian prolongation, an alternative culture appeared, making this scenario of linear evolution more complex. Based on early data on the Mediterranean microlaminar Epipalaeolithic of the Spanish Levant and southern Catalonia, and now from the north of Iberian Catalonia, Andorra and Ariège, the hypothesis of an Epipalaeolithic or early Aziloid or Proto-Azilian facies, contemporary with the last Magdalenians (Barbaza, 1984, 1989, 1997, 2008; Martzluff, 1994, 2008, 2009) has been proposed. The Azilian may thus have emerged precociously, in competition with the Upper Magdalenian, in the Mediterranean regions of the Iberian Peninsula where it would have radiated towards the north. The argument of the " ${ }^{\text {14 } C}$ plateau" established by the calibration curves, sometimes advanced to find a classic linear developmental dynamic as an alternative to this interpretation, does not appear to be exempt from doubtful presuppositions, since, when examined closely, this phenomenon concerns only the rather late dates for the first Azilian levels of Rhodes II, and neither those provided by the lower level (layer 10) of la Balma Margineda, nor those from the Late Magdalenian of layer 7 at Troubat. Moreover, to accept this "plateau effect", which would contradict the cultural-chronological smoothing of the Alleröd industries in line with habitual standards a plateau, which in addition is not indicated for this period (Langlais, 2010, p. 438, Fig. 345) - would be to admit a sudden challenge to bone technology between the late Upper Magdalenian and the Proto-Azilian of Rhodes II-F5 or Margineda layer 10 type, while certain evidence for continuity exists between this Late Magdalenian (cf. Phase VIII of César Gonzalez Sainz) and the classic Pyrenean Azilian, which borrowed some characteristic elements from earlier phases, such as the "flat" red deer antler harpoons (Thomson, 1954) and which maintained, despite what has been said, a substantial osseous industry. Based on indications provided by the sites of the northern slope of the Pyrenees, and particularly from Troubat, three possible scenarios can be envisaged to illustrate the succession from the Upper Magdalenian to the classic Pyrenean Azilian of the Troubat layer 6 type. The first hypothesis would involve either an Azilianisation process, initially very discreet (Troubat layer 7) and then sudden, of the Late Magdalenian, which loses (Troubat layer 6) all its "Magdalenianish" characteristics other than the use of harpoons (which in contrast are totally absent from the earlier phases of the early Epipalaeolithic - Proto-Azilian). According to the second hypothesis, there would have been a clear lack of sedimentation between layers 7 and 6 at Troubat - for which there is no evidence in which we would insert the lower levels of Rhodes II and layer 10 from la Margineda. Finally, the third hypothesis purports a strong cultural independence between the two assemblages without no other links at the site than those provided by the chronological succession and immediate stratigraphic proximity of a Late Magdalenian, which continued for some time, like its Cantabrian counterparts, and an Azilian already in its classic phase (Fig. 8).

During the final period of the Palaeolithic, material cultures in Italy and southern France to the east of the Rhône underwent a linear post-Gravettian development (Epigravettian, Tardigravettian developing into Aziloid facies: Romanelian, Bouverian, Valorguian, etc.) until the appearance of numerous Sauveterrian geometric microlithic industries around 10,000 BP. In contrast, Spain and France were pervaded by the two original cultural phenomena of the Solutrean and the Magdalenian, until the time at which the socio-economic structures of the latter were attacked by the first effects of generalised environmental warming, and lost their coherence in favour of the "Mediterranean" cultural foundation. The phenomenon was earlier in the Mediterranean part of the Iberian Peninsula where the "Magdalenisation" of the industries did not occur on the basis of principles as rigid as those on the Cantabrian region, to the north of the Pyrenees and beyond, in the whole great North European Plain. According to the stratigraphies, the techno-typological data and the chronology, therefore, the Pyrenean Azilian can be structured into two distinct phases:

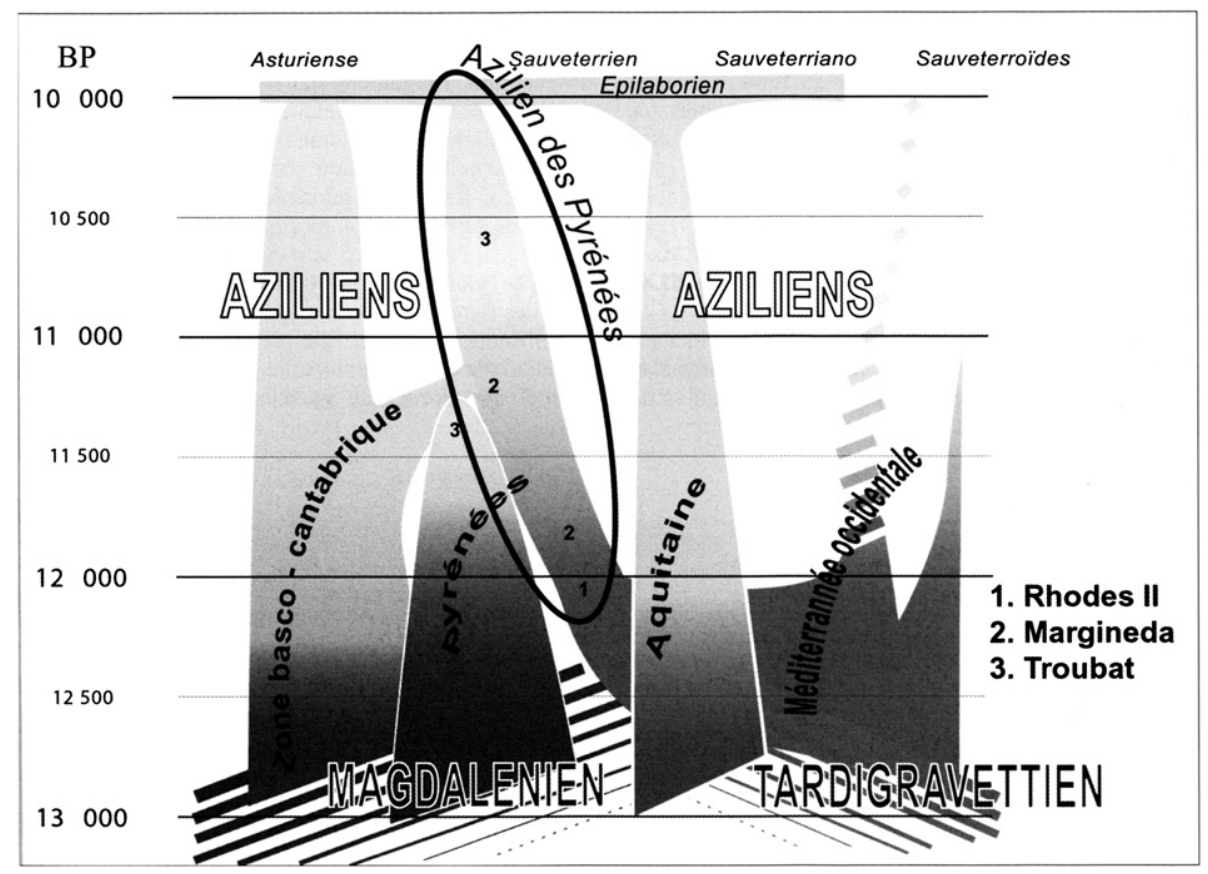

Fig. 8. Classic Pyrenean Azilian in the concert of the tardiglacial cultures. 
- An earlier phase, exclusively lithic like the Epipalaeolithic facies of Mediterranean Spain, contemporary with the final moments of the Cantabrian Magdalenian during the 12th millennium BP (Phase VIII of César Gonzalez Sainz, which shows that if layer 7 at Troubat is isolated "between the Rhône and Ebro", it is not so in the Cantabrian-Pyrenees context). In this context, the deposit of Hort de la Boquera (Catalonia) offers the opportunity for a technological study of the lithic assemblages, which partly illustrates the technological interventions that occurred during the Bölling, south of the Pyrenees. This early Proto-Azilian phase, which developed during the Alleröd, would correspond to the industries of Rhodes II-F5 and layer 10 of Margineda, while to the north of the Garonne and in Cantabria, the Upper Magdalenian progressively adopted "Azilian" characteristics.

A classic phase with an unchanged lithic industry (65\% backed points, $15 \%$ splintered pieces and $15 \%$ scrapers), which appears to have inherited from the Cantabrian Magdaleno-Azilian, the bone industry which it prolonged with some success from the end of the 12th and during the 11th millennium before present. Original symbolic expressions (painted or engraved pebbles, engraved personal ornaments, etc.), which had firmer roots in the Tardigravettian systems of notation and representation than in the Magdalenian representations, appear. Margineda layer 8, Dufaure layer 3, Troubat layer 6, Arancou layer 3, together with a large part of the archaeological deposits from the left bank of Mas d'Azil, would emerge during the Younger Dryas from these two previous cultures. At that moment, a truly original material and spiritual culture existed on the northern slope of the Pyrenees and its margins (Barbaza and Lacombe, 2005). It came to an end during the transitional period of the 11th to 10th millennia BP, when the short "Azilianizing" episode of the Epilaborian became general. The Sauveterrian Mesolithic followed shortly after.

Despite local continuations, confronted with new living conditions in a space increasingly enclosed by the conquering vegetation, the Magdalenian gradually gave way; its social and cultural cohesion crumbled and enabled the development of new cultural expressions. During this period of change, which began with the start of the Bölling-Alleröd interstadial, subsistence systems do not appear to have been suddenly and profoundly affected by the replacement of steppe game species by forest ones. Hunting specialisation remained discrete and the broadening of the spectrum of meat-based resources corresponded more to qualitative or aesthetic concerns than to quantitative ones. Fish, above all salmon, were present and sometimes in large quantities, but they were equally so in the Upper Magdalenian. In fact, in terms of what is perceptible in the archaeological record, neither the interstadial warming nor the cooling in the Younger Dryas seem to have challenged the fundamental principles of subsistence, and hunting of new species enabled the prolongation, for a time, of a sort of Palaeolithic lifestyle. In contrast, the methods imposed by the hunting of these forest animals, with small herds had replacing large ones, profoundly affected collective practices and the whole system of lifeways that resulted from them. In so far as it can be considered as a homogeneous whole, the Magdalenian appears to have lost, albeit at variable rates, its social coherence and therefore its cultural coherence, in all senses of the term. It made room for other general structures within which the new material culture and the new "Mediterranean" artistic expressions gradually imposed themselves to give birth to the Azilian. In the details of its technological characteristics and industries, this Azilian cannot be perceived as the direct material expression of an adaptive system, but must rather be perceived as the deployment of a new cultural expression whose symbolic expressions are a striking illustration.
In happy contradiction with a narrow deterministic logic, the late Dryas did not arrest the phenomenon.

\section{Acknowledgments}

This paper profited from the suggestions of an anonymous reviewer and L.G. Straus, who also extensively edited the English.

\section{References}

Altuna, J., Mariezkurrena, K., 1995. Les restes osseux de macromammifères. In: Straus, L.G. (Ed.), Les derniers chasseurs de rennes du monde pyrénéen. L'abri Dufaure: un gisement tardiglaciaire en Gascogne, t. XXII. Mémoire de la Société Préhistorique Française, pp. 181-212.

Altuna, J., Mariezkurrena, K., 1996. Faunes de mammifères des gisements magdaléniens du Pays basque et zones limitrophes. In: Delporte, H., Clottes, J. (Eds.), Pyrénées préhistoriques, arts et sociétés, 118e Congres du CTHS, Pau, 1993. Ed. du Comité des Travaux Historiques et Scientifiques, Paris, pp. 149-162.

Andrieu, V., 1991. Dynamique du paléoenvironnement de la vallée montagnarde de la Garonne (Pyrénées centrales, France) de la fin des temps glaciaires. Thèse de l'Université de Toulouse Le Mirail, 330 p.

Aparicio-Perez, J., 1979. El Mesolitico de la region de Valencia y en el Mediterraneo occidental. Servicio de Investigacion Prehistorica, 297 p., 57 fig., V pl.

Arambourou, R., Delpech, F., Evin, J., Laurent, P., Paquereau, M.-M., Schvoerer, M., Thibault, C., 1978. Le gisement préhistorique de Duruthy à Sorde l'Abbaye (Landes). Mémoire de la Société Préhistorique Française 13, 158. 82 fig.

Barandiaran, I., Cava, A., 1994. Zatoya, sitio magdaleniense de caza en medio pirenaïco. In: Homenaje al Dr Gonzalez-Echegaray. Ed. Museo y Centro de Investigacion de Altamira, pp. 71-85.

Barbaza, M., 1981. Recherches sur l'Epipaléolithique en Languedoc et Catalogne. Thèse de Doctorat. Ecole des Hautes Etudes en Sciences Sociales, Toulouse, 480 p., 105 fig.

Barbaza, M., 1984. L'Epipaléolithique méditerranéen espagnol Thème, concepts et problèmes. Travaux de l'Institut d'Art Préhistorique de Toulouse, Toulouse, pp. 3-14.

Barbaza, M., 1989. Cultures et société au Paléolithique terminal, au Mésolithique et au début du Néolithique ancien dans le sud-Ouest de I'Europe. Mémoire HDR, Université de Toulouse-Le Mirail, exemplaire multigraphié, 1192 p., 292 fig.

Barbaza, M., 1996a. Le Magdalénien supérieur final et 1'Azilien dans les Pyrénées centrales. La grotte-abri du Moulin à Troubat (Hautes-Pyrénées) et son contexte. In: Delporte, H., Clottes, J. (Eds.), Pyrénées préhistoriques arts et sociétés, 118e Congres du Comité des Travaux Historiques et Scientifiques, Pau, 1993. Ed. CTHS, Paris, pp. 311-326.

Barbaza, M., 1996b. Le Magdalénien terminal des Pyrénées françaises. In: L’art préhistorique des Pyrénées. Ed. de la Réunion des Musées Nationaux, Paris, pp. 124-131.

Barbaza, M., 1997. L’Azilien des Pyrénées dans le contexte des cultures de la fin du Tardiglaciaire entre France et Espagne. Bulletin de la Société Préhistorique Française 94 (3), 315-318.

Barbaza, M., 1999. Les civilisations postglaciaires. La vie dans la grande forêt tempérée. Ed. La Maison des Roches, Paris. 128 p.

Barbaza, M., 2008. Les industries des couches 10 à 8 de la Balma de la Margineda: des données fondamentales pour une approche de l'Azilien pyrénéen. In: Guilaine, J., Barbaza, M., Martzluff, M. (Eds.), Les excavaciones a la Balma de la Margineda, t. 4. Edicions del Govern d'Andorra, Andorra la Vella, pp. 540-573.

Barbaza, M., Heinz, C., 1992. La grotte-abri du Moulin (Troubat, Hautes-Pyrénées). Environnement et Archéologie. In: Vernet, J.L. (Ed.), Les charbons de bois. Les anciens écosystèmes et le rôle de l'Homme. Colloque de Montpellier. 10-13 sept. 1991. Bulletin de la Société Botanique de France, t. 139, pp. 685-695.

Barbaza, M., Lacombe, S., 2005. L'Azilien pyrénéen: une culture originale? In: Jaubert, J., Barbaza, M. (Eds.), Territoires, déplacements, mobilité, échanges durant la Préhistoire, 126e Congres du Congres du Comité des Travaux Historiques et Scientifiques, Toulouse, 2001. Ed. CTHS, Paris, pp. 421-428.

Barbaza, M., Martzluff, M., 1995. Epipaleolithique et Mésolithique au Nord des Pyrénées. In: 20 anys d'Arqueologia Pirinenca, Homentage a Prof. J. Guilaine. Xe Colloqui intemacional d'Arqueologia de Puigcerda, 1994, pp. 177-183.

Barbaza, M., Fritz, C., Pomie, S., 1998. Une pendeloque gravée azilienne à Troubaten-Barousse. Préhistoire Ariégeoise LIII, 141-174.

Beaudoin, C., Jouet, G., Suc, J.P., Berne, S., Escarguel, G., 2007. Vegetation dynamics in southern France during the last $30 \mathrm{ky} B \mathrm{P}$ in the light of marine palynology. Quaternary Science Reviews 26, 1037-1054.

Beaulieu, J.-L.de, Pons, A., Reille, M., 1988. Histoire de la flore et de la végétation du Massif Central (France) depuis la fin de la dernière glaciation. Cahier de micropaléontologie 3, 5-36.

Bergadà, M.M., 1998. Estudio geoarqueológico de los asentamientos prehistóricos del Pleistoceno Superior y el Holoceno inicial en Catalunya. BAR International Series, 742. Oxford.

Bridault, A., Fontana, L., 2003. Enregistrement des variations environnementales par les faunes chassées, dans les zones de moyenne montagne d'Europe occidentale, au Tardiglaciaire et au début de 1'Holocene. In: Patou-Mathis, M., Bocherens, H. (Eds.), Le rôle de I'environnement dans les comportements des 
chasseurs-cueilleurs préhistoriques, Colloque 3.1, actes du XIVe Congres UISPP, Liége, 2001. BAR 1105, pp. 55-65.

Bridault, A., Chaix, L., Pion, G., Oberlin, C., Thiebault, S., Argant, J., 2000. Position chronologique du renne (Rangifer tarandus L.,) à la fin du Tardiglaciaire dans les Alpes du Nord françaises et le Jura méridional. In: Pion, G. (Ed.), Le Paléolithique supérieur récent: nouvelles données sur le peuplement et l'environnement, Table ronde de Chambéry, 1999, t. 28. Mem. SPF, pp. 47-57.

Cacho, C., Fumanal, M.P., Lopez, P., Lopez, N., 1983. Contribution du Tossal de la Roca (Alicante) à la chronologie du Paléolithique supérieur final dans la région de Valence (Espagne). Colloque UISPP. La position taxonomique et chronologique des industries à pointes à dos autour de la Méditeranée européenne. Sienne. Rivista di Scienze Preistoriche 38, 11-22.

Cacho, C., 1989. Structuration du Magdalénien dans l'Espagne méditerranéenne. Actes du colloque de Mayence, Le Magdalénien en Europe, pp. 459-473, 5 fig.

Clottes J. \& Simonnet R., 1979. Le Paleolithique fi nal dans le bassin de Tarascon-surAriege, d'apres les gisements des Eglises (Ussat) et de Rhodes II (Arignac). In: Sonneville-Bordes D. de (dir). La fi $n$ des temps glaciaires en Europe, chronostratigraphie et écologie des cultures du Paléolithique fi nal: 647-659. Colloques internationaux du CNRS $n^{\circ} 271$, Talence, 1977. Paris: CNRS.

Cochard, D., 2004. Les Léporidés dans la subsistance des Paléolithiques du Sud de la France. Thèse de Doctorat, Université de Bordeaux I, 346 p., ex. multigraph.

Costamagno, S., 1999. Stratégies de chasse et fonction des sites au Magdalénien dans le Sud de la France. Thèse de Doctorat, Université de Bordeaux I, 495 p. ex. multigraph.

Costamagno, S., 2003. L'exploitation des Ongulés au Magdalénien dans le Sud de la France. In: Costamagno, S., Laroulandie, V. (Eds.), Mode de vie au Magdalénien: les apports de l'archéozoologie. Oxford, BAR International Series, 1144, Liège, XIVème congrès UISPP, pp. 73-88.

Costamagno, S., 2005. Mobilité, territoire de chasse et ressources animales au Magdalénien final en contexte pyrénéen: le niveau 7 a de la grotte-abri du Moulin (Troubat, Hautes-Pyrénées). In: Jaubert, J., Barbaza, M. (Eds.), Territoires, déplacements, mobilité, échanges durant la Préhistoire. Ed. du Comité des Travaux Historiques et Scientifiques, pp. 371-382.

Costamagno, S., Laroulandie, V., Langlais, M., Cochard, D., 2009. Exploitation du monde animal sur le versant Nord des Pyrénées au Tardiglaciaire. In: Els Pirineus i les ares circumdants durant el Tardiglacial. Mutations i filiacions, XIV col-loqui internacional d'Arqueologia de Puigcerda, pp. 185-210, 5 fig.

Costamagno, S., Liliane, M, Cedric, B, Bernard, V., Bruno, M., 2006. Les Pradelles (Marillac-le-Franc, France): A Mousterian reindeer hunting camp? Journal of Anthropological Archaeology 25, 466-484.

Dachary, M., 2002. Le Magdalénien des Pyrénées occidentales. Thèse de Doctoral, Université de Paris X, ex. multigraph, 300 p.

Dachary, M., 2009. Une perception affinée du Magdalénien des Pyrénées occidentales à partir des travaux récents. Els Pirineus i les ares circumdants durante el Tardiglacial. Mutacions i liliacions, technoculturals, evolucio paleoambiental (16000-10000 BP.). In: Actes du Colloque de Puigcerda, Nov. 2006, pp. 423-459, 6 fig.

Delpech, F., 1983. Les faunes du Paléolithique supérieur dans le Sud-Ouest de la France. Cahiers du Quaternaire.

Delpech, F., 1989a. L'environnement animal des magdaléniens. In: Rigaud, J.-P. (Ed.), Le Magdalénien en Europe, Colloque de Mayence, 1987. ERAUL 38, pp. 5-30.

Delpech, F., 1989b. Le temps de 1'Antilope saïga. In: Mohen, J.P. (Ed.), Le temps de la Préhistoire. Société Prehistorique Française et Archéologia, pp. 48-49.

Delpech, F., 1992. Le monde magdalénien d'après le monde animal. In: Rigaud, J.P., Laville, H., Vandermeersch, B. (Eds.), Le peuplement magdalénien. Paléogéographie physique et humaine, Colloque de Chancelade, 1988. Ed. CTHS, Paris, pp. 127-135.

D’Errico, F., 1995. L'art gravé trouvé par la fouille Breuil-Dubalen. In: Straus, L.G. (Ed.), Les derniers chasseurs de rennes du monde pyrénéen. L'abri Dufaure: un gisement tardiglaciaire en Gascogne, t. XXII. Mémoire de la Société Préhistorique Française, pp. 253-260.

Eastham, A., 1995. L'écologie avienne. In: Straus, L.G. (Ed.), Les derniers chasseurs de rennes du monde pyrénéen. L'abri Dufaure: un gisement tardiglaciaire en Gascogne, t. XXII. Mémoire de la Société Préhistorique Française, pp. 219-234.

Fernandez-Tresguerres, J.A., 1995. El Aziliense de la region cantabrica. In: Moure Romanillo, A., Gonzalez Sainz, C. (Eds.), El final del Paleolitico cantdbrico. Ed Universidad de Cantabria, pp. 199-224.

Fontana, L., 2003. Characterization and exploitation of the Arctic Hare (Lepus timidus) during the Magdalenian: surprising data from Gazel cave (Aude, France). In: Costamagno, S., Laroulandie, V. (Eds.), Mode de vie au Magdalénien: apports de I'archéozoologie, Colloque 6.4, actes du XIVe Congres UISPP, Liège, 2001. BAR 1144, pp. 101-118.

Fortea-Perez, J., 1973. Los complejos microlaminares y geometricos del Epipaleolitico mediterraneo espanol. Universidad de Salamanca, 550 p., 16 tab., 114 fig., XV pl.

Fosse, P., Quiles, J., 2006. Tafonomia y arqueozoologia comparadas de algunos yacimientos de los Pirineos franceses y de Cantabria. In: Homenaje a Jesus Altuna. Munibe, vol. 57, pp. 163-181.

Fullola, J.M., 1990. La Prehistoria del Montsant. Ed. CRPP, Falset. 77 p.

García-Argüelles, P., 1993. Antecedentes y evolución del Epipaleolítico de las comarcas meridionales de Cataluña. Dins: Homenaje a Miquel Tarradell. Barcelona: Curial Edicions Catalanes, pp. 130-137.

Garcia-Argüelles, P., Nadal, J., Fullola, J.M., 1999. L'Epipaléolithique en Catalogne: données culturelles et paléoenvironnementales. In: Bintz, P., Thévenin, A. (Eds.), L'Europe des derniers chasseurs. Peuplement et paléoenvironnement de
l'Epipaléolithique et du Mésolithique. 5ème colloque UISPP, Grenoble 1995. Ed. du CTHS, pp. 79-85.

Geddes, D., Barbaza, M., Vaquer, J., Guilaine, J., 1986. Tardiglacial and Postglacial in the eastern Pyrennes and westerne Languedoc (France). In: Straus, L.G. (Ed.) The end of the Paleolithic in the Old Word. BAR International Series 284, 228 p. pp. 63-80.

Gonzalez Sainz, C., 1995. 13 000-11000 B.P. El final de la época magdaleniense en la region cantabrica. In: A. Moure Romanillo, Gonzalez Sainz, C. (Eds.), El final del Paleolitico cantabrico. Universidad de Cantabria, pp. 159-197. 1 fig.

Gonzalez Sainz, C., 1989. El Magdaléniense Superior-final de la region cantabrica. Universidad de Cantabria, Tantin, Santander. 318 p.

Gonzalez-Samperiz, P., Valero-Garces, B.L., Moreno, A., Jalut, G., Garcia-Ruiz, J.M. Marti-Bono, C., Delgado-Huertas, A., Navas, A., Otto, T., Dedoubat, J.J., 2006 Climate variability $m$ the Spanish Pyrenees during the last 30,000 yrs. revealed by el Portalet sequence. Quaternary Research 66, 38-52.

Grousset, F., 2001. Les changements abrupts du climat depuis 60000 ans. Quaternaire 12, 203-211.

Guilaine, J., Barbaza, M., Martzluff, M., 2008. Las excavaciones a la Balma Margineda t. 4. Edicions del Govern d'Andorra. 597 p.

Fontana L., 1998. Subsistance et territoire au Magdalénien supérieur dans les Pyrénées: l'apport des données archéozoologiques de la grotte de Belvis (Aude) Préhistoire du Sud-Ouest t. 5 n. 2.

Heinz, C., 2005. Transformations du milieu et adaptations humaines, du Tardiglaciaire à l'Holocène: les stratégies pyrénéennes. In: Tuffreau, A. (Ed.), Peuplements humains et variations environnementales au Quaternaire. Actes du colloque de Poitiers, 2000. BAR 1352, pp. 133-138.

Heinz, C., Barbaza, M., 1998. Environmental changes during the Late Glacial and Post-Glacial in the central Pyrenees (France): new charcoal analysis and archeological data. Review of Paleobotany and Palynology 942 Amsterdam.

Jalut, G., Delibrias, G., Dagnac, J., Mardones, M., Bouhours, M., 1982 A palaeoecological approach to the last 21,000 years in the Pyrénées: the peat bog of Freychinède (alt. $1350 \mathrm{~m}$., Ariége, South France). Palaeogeography, Palaeoclimatology, Palaeoecology 40, 321-359.

Jalut, G., Andrieu, V., Delibrias, G., Fontugne, M., Pages, P., 1988. Palaeoenvironment of the valley of Ossau (Western French Pyrénées) during the last $27 \backslash 000$ years. Pollen et Spores 30, 357-394.

Jalut, G., Aubert, S., Galop, D., Fontugne, M., Belet, J.M., 1996. France. Type region F$\mathrm{zg}$ and F-r, the northern slope of the Pyrenees. In: Berglund, B.E., Birks, H.J.B Ralska-Jasiewiczowa, E., Wright, H.E. (Eds.), Palaeoecological events during the last 15000 years; Regional Syntheses of Palaeoecological studies of Lakes and Mires in Europe. Wiley, Chichester, UK, pp. 612-632.

Jalut, G., Galop, D., Belet, J.M., Aubert, S., Esteban, A., Bouchette, A., Dedoubat, J.-J., Fontugne, M., 1998. Histoire des forêts du versant Nord des Pyrénées au cours des 30000 dernières années. Journal de la Société Botanique Française 5, 73-84.

Jalut, G., Montserrat Marti, J., Fontugne, M., Delibrias, G., Vilaplana, J.M., Julia, R., 1992. Glacial to interglacial vegetation changes in the northern and southern Pyrenees: deglaciation, vegetation cover and chronology. Quaternary Science Reviews XI, 449-480.

Jalut, G., Turu i Michels, V., 2009. La végétation des Pyrnées françaises lors du dernier épisode glaciaire et durant la transition glaciaire-Interglaciaire (Last Termination). In: Els Pirineus i les ares circumdants durant el Tardiglacial. Mutations i filiacions, XIV col-loqui internacional d'Arqueologia de Puigcerda, pp. 129-149, 6 fig.

Kozlowski, J., 1989. Commentaire du rapport de Mme Carmen Cacho: la Structuration du Magdalénien dans l'Espagne méditerranéenne (pp. 459-473). In: Actes du colloque de Mayence, Le Magdalénien en Europe, pp. 474-475.

Kuntz, D., Costamagno, S. Relationships between reindeer and man in southwestern France during the Magdalenian. Quaternary International 238, in press.

Lacombe, S., 1998a. Préhistoire des groupes culturels au Tardiglaciaire dans les Pyrénées centrales. Apports de la technologie lithique. Thèse de Doctorat Université de Toulouse-Le Mirail, ex. multigraph, 385 p.

Lacombe, S., 1998b. Stratégies d'approvisionnement en silex au Tardiglaciaire. L'exemple des Pyrénées centrales françaises. Préhistoire Ariègeoise L1II 223-266

Lacombe, S., 2005. Territoires d'approvisionnement en matières premières lithiques au Tardiglaciaire. Remarques a propos de quelques ensembles pyrénéens. In: Jaubert, J., Barbaza, M. (Eds.), Territoires, déplacements, mobilité, échanges durant la Préhistoire, 126e Congres du Comité des Travaux Historiques et Scientifiques, Toulouse, 2001. Ed. CTHS, Paris, pp. 329-353.

Lacombe, S., 2008. Approche pétro archéologique du silex des niveaux aziliens de la Balma de la Margineda. In: Guilaine, J., Barbaza, M., Martzluff, M. (Eds.), Les excavaciones a la Balma de la Margineda, t. 4. Edicions del Govern d'Andorra, Andorra la Vella, pp. 540-573.

Langlais, M., 2010. Les sociétés magdaléniennes de l'isthme pyrénéen. In: Ed. du Comité des Travaux Historiques et Scientifiques, Paris, série Documents préhistoriques, t. 26337 p.

Langlais, M., Mangado, J., 2007. Le Magdalénien entre le Rhône et 1'Ebre: Des frontières naturelles et culturelles vécues par les Préhistoriques et perçues par les Préhistoriens? In: Cazals, N., Gonzalez Urquijo, J., Terradas, X. (Eds.), Frontières naturelles et frontières culturelles dans les Pyrénées préhistoriques. Actes de la table ronde de Tarascon-sur-Ariège, 11-13 mars 2004 Monografias del Instituto Intemacional de Investigaciones de Cantabria, 2, Santander, pp. 143-163.

Laroulandie, V., 2000. Taphonomie et archéozoologie des Oiseaux en grotte: applications aux sites paléolithiques du Bois-Ragot (Vienne), de Combe- 
Saunière (Dordogne) et de La Vache (Ariège). Thèse de Doctorat, Université de Bordeaux I, ex. multigraphié, 396 p.

Laroulandie, V., 2003. Exploitation des Oiseaux au Magdalénien en France: état des lieux. In: Costamagno, S., Laroulandie, V. (Eds.), Mode de vie au Magdalénien: les apports de l'archéozoologie. Oxford BAR International Series, 1144, pp. 129-138.

Le Gall, O., 1992. Les Magdaléniens et 1'ichtyofaune dulçaquicole. In: Rigaud, J.-P., Laville, H., Vandermeersch, B. (Eds.), Le peuplement magdalénien. Paléogéographie physique et humaine, Colloque de Chancelade, 1988. Ed. CTHS, Paris, pp. 277-285.

Le Gall, O., 1999. Eléments de réflexion sur la pêche dans le Bassin méditerranéen nord occidental pendant le développement des faciès leptolithiques. In: Saccchi, D. (Ed.), Les faciès leptolithiques du Nord-Ouest méditerranéen: milieux naturels et culturels, CPF, XXI Ve session, Carcassonne, 1994. Soc. Prehist. Fr., pp. 251-265.

Le Gall, O., 2003. Des Magdaléniens et. des poissons. In: Costamagno, S., Laroulandie, V.(Eds.), Mode de vie au Magdalénien: apports de I'Archéozoologie, Colloque 6.4, actes du XIVe Congres UISPP, Liège, 2001. BAR 1144, pp. 119-128.

Magny, M., 1995. Successive Oceanic and Solar forcing indicated by Younger Dryas and Early Holocene climatic oscillations in the Jura. Quaternary Research 43 , 279-285.

Martin, H., 1994. Nouveaux milieux, nouveaux chasseurs. Une approche des comportements au Postglaciaire au travers de l'étude des saisons de capture du gibier. Thèse de Doctorat, Université de Toulouse Le Mirail, 383 p.

Martzluff, M., 1994. Filiations et mutations des industries lithiques au début de I'holocène dans les Pyrénées catalanes: Epipaléolithique, Mésolithique et Néolithique ancien de la Balma Margineda (Andorre) et en Roussillon (P.-O.) Thèse de Doctorat, Université de Perpignan, 5 tomes, 1040 p., ex. multigraph.

Martzluff, M., 2008. Evolution du débitage lithique dans la séquence azilienne de la Balma de la Margineda. In: Guilaine, J., Barbaza, M., Martzluff, M. (Eds.), Les excavaciones a la Balma de la Margineda. Edicions del Govern d'Andorra, Andorra la Vella, pp. 574-594.

Martzluff, M., 2009. L'azilien pyrénéen entre Garonne et Ebre: un état de la question. Els Pirineus i les arees circumdants durant el tardiglacial. In: Actes du Colloque de Puigcerda, Novembre 2006, pp. 375-422.

Montoya, C., 2004. Les traditions techniques lithiques à l'Epigravettien: analyses de séries du Tardiglaciaire entre Alpes et Méditerranée. Thèse de Doctorat, Université d'Aix-en-Provence, ex. multigraph, 587 p.

Montserrat, J.M., 1992. Evolucion Glaciar y Postglaciar del Clima y la Vegetacion en la vertiente Sur del Pirineo, estudio palynologico. Ed. CSIC, Madrid.

Naughton, F., Sanchez Goni, M.F., Desprat, S., Turon, J.L., Duprat, J., Malaize, B. Joli, C., Cortijo, E., Drago, T., Freitas, M.C., 2007. Present-day and past (last 25000 years) marine pollen signal off western Iberia. Marine Micropaleontology 62, 91-114.

Petit-Mendizabal, M.A., 1998. Posar a l'hora el rellotge de la prehistoria: calibracio de les datacions radiocarboniques de la prehistoria moianesa. Modilianum 19, 84-100. Moia.

Rasmussen, S.O., Andersen, K.K., Svensson, A.M., Steffensen, J.P., Vinther, B.M. Clausen, H.B., Siggaard-Andersen, M.-L., Johnsen, S.J., Larsen, L.B., DahlJensen, D., Bigler, M., Rothlisberger, R., Fischer, H., Goto-Azuma, K., Hansson, M.E., Ruth, U., 2006. A new Greenland ice core chronology for the last glacial termination. Journal of Geophysical Research 111.

Reille, M., 1990. La tourbière de la Borde (Pyrénées-orientales, France): un site clé pour 1'étude du Tardiglaciaire sud-européen. Comptes-rendus de I'Académie des Sciences de Paris 310, 823-829.

Reille, P., Andrieu, V., 1995. The late Pleistocene in Lourdes basin, Western Pyrénées, France: new pollen analytical and chronological data. Vegetation History and Archaeobotany 4, 1-21.
Reimer, P.J., Baillie, M.G.L., Bard, E., Bayliss, A., Beck, J.W., Bertrand, C.J.H., Blackwell, P.G., Buck, C.E., Burr, G.S., Cutler, K.B., Damon, P.E., Edwards, R.L., Fairbanks, R.G., Friedrich, M., Guilderson, T.P., Hogg, A.G., Hughen, K.A., Kromer, B., MacCormac, G., Manning, S., Bronk Ramsey, C., Reimer, R.W., Remmele, S., Southon, J.R., Stuiver, M., Talamo, S., Taylor, F.W., Van Der Plight, J., Weyhenmeyer, C.E., 2004. IntCal04 terrestrial radiocarbon age calibration, $0-26$ cal kyr B.P. Radiocarbon 46 (3), 1029-1058.

Simonnet, R., 1967. L'abri sous roche de Rhodes II et la question de 1'Azilien dans les Pyrénées françaises. Note préliminaire. Bulletin de la Société Préhistorique Française 64, 175-186.

Simonnet, R., 1983. Stratigraphie du Magdalénien final et de l'Azilien à Rhodes II, commune d'Arignac, Ariège. Bulletin de la Société Préhistorique Française 80, $12-13$.

Sacchi, D., 1986. Le Paléolithique supérieur du Languedoc occidental et du Roussillon. In: Gallia Préhistoire. XXIe suppl 284 p. dv.

Sanchez Goni, M.F., 1996. Les changements climatiques du Paléolithique supérieur. Enquête sur le rapport entre Paléoclimatologie et Préhistoire. Zephyrus 49, 3-36.

Sanchez Goni, M.F., 2006. Interactions végétation-climat au cours des deniers 425000 ans en Europe occidentale. Le message du pollen des archives marines. Quaternaire 17 (1), 3-25.

Sanchez Goni, M.F., Turon, J.L., Eynaud, F., Gendreau, S., 2000. European climatic response to millennial-scale changes in the atmosphere-ocean system during the last glacial period. Quaternary Research 54, 394-403.

Seronie-Vivien, M., 1995. In: Straus, L.G. (Ed.), Les derniers chasseurs de rennes du monde pyrénéen. L'abri Dufaure: un gisement tardiglaciaire en Gascogne. Mémoire de la Société Préhistorique Française, t. XXII, pp. 125-126.

Sommer, R.S., Zachos, F.E., Street, M., Jöris, O., Skog, A., Benecke, N., 2008. Late Quaternary distribution dynamics and phylogeography of the red deer (Cervus elaphus) in Europe. Quaternary Science Reviews 27, 714-733.

Straus, L.G., this issue. Were there human responses to younger dryas in cantabrian spain? Quaternary International.

Straus, L.G., 1985. Chronostratigraphy of the Pleistocene-Holocene transition: the Azlian problem in the Franco-Cantabrian region. Palaeohistoria 27, 89-122.

Straus, L.G. (Ed.), 1986a. The End of the Paleolithic in the Old Word. BAR International Series 284228 p.

Straus, L.G., 1986b. The end of the Paleolithic in Cantabrian Spain and Gascony. In: Straus, L.G. (Ed.), The End of the Paleolithic in the Old World. British Archaeological Research International Series 284, pp. 81-116.

Straus, L.G., 1992. L'abri Dufaure et la falaise du Pastou dans le système adaptatif régional des Pyrénées au Magdalénien. In: Le peuplement magdalénien. Paléogéographie physique et humaine, Colloque de Chancelade, 1988. Ed. Comité des Travaux Historiques et Scientifiques, Paris, pp. 335-344.

Straus, L.G., 1995. In: Les derniers chasseurs de rennes du monde pyrénéen. L’abri Dufaure: un gisement tardiglaciaire en Gascogne, t. XXII. Mémoire de la Société Préhistorique Française 287 p., nombreuses figures et nombreux tableaux.

Thomson, N.W., 1954. Azilian harpoons. In: Proceedings of the Prehistory Society, XX, pp. 193-211.

Tosello, G., 2003. Pierres gravées du Périgord magdalénien. Art, symboles et territoires. In: XXXVIème supplément à Gallia-Préhistoire. Ed. CNRS, Paris. 577 p., 392 fig.

Vaquero, M., 2004. Els darrers caçadors recollectors de la conca de Barbera: el jaciment del Moli del Salt (Vimbodi). Centres d'Estudis de la Conca de Barbera, Montblanc.

Vilaseca-Angura, S., 1973. Reus y su entorno en la Prehistoria Reus, 284 p., 174 fig., 144 p.. h.t., 2 volumes. 